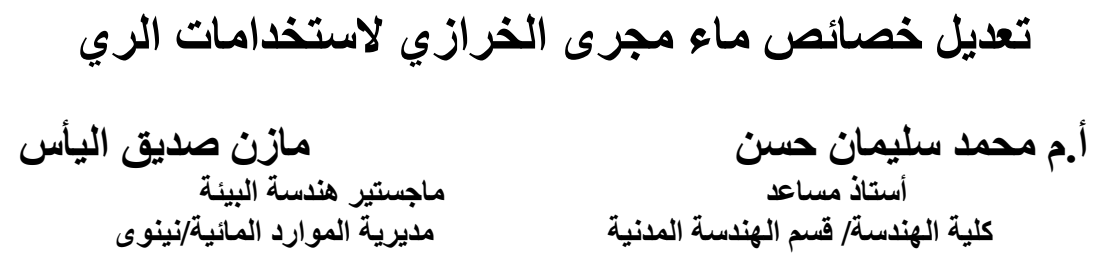

الخلاصة

تم في هذا البحث معالجة(30) نموذجا من مياه مجرى الخرازي وهي مزيج من مياه الفضلات المنزلية والزراعية ومياه

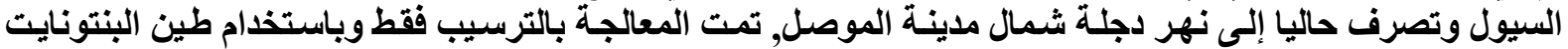

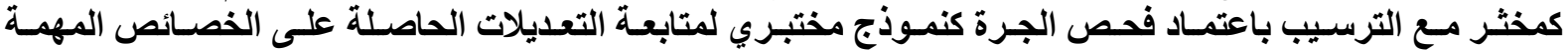
لاستخدامات الري.

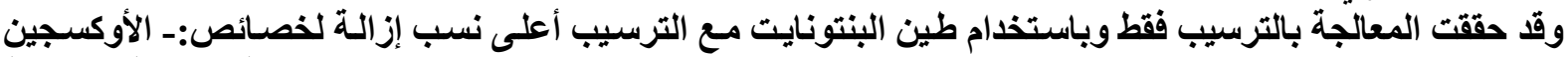

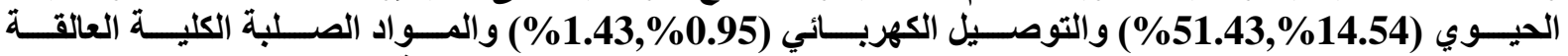

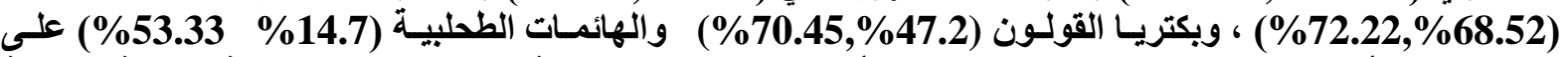
التو الي بحيث أصبح الماء المستصلح مناسبا لسقي الأشجار والمحاصيل العلفية حسب محددات منظمـة الصحة العالميـة .WHO الكلمات الدالة :- طين البنتونايت ,استصلاح المياه ,إعادة استخذام المياه , مجرى الخرازي .

\title{
Water Reclamation of Kharazi Wadi for Irrigation
}

\section{Mohammed Sulaiman Hassan \\ Civil Engg. Dept}

\author{
Mazin Siddek Alyas \\ Ministry Of Water Resources
}

\begin{abstract}
In the present research Thirty raw water samples were collected from kharazi wadi for further treatment , Those samples represent a mixture of (municipal, irrigation and storm) sewage discharged directly to Tigris river north Mosul city .The Jar test technique was conducted to measure the variation of the main important characteristics of irrigation water. The treatment was carried out using bentonite clay as a coagulant compared with the treatment by sedimentation only. The results showed that the bentonite clay was more effective in removing :BOD, EC, TSS, Coliform bacteria and phytoplanktonic algae and max\% removal recorded were $(\% 51.43, \% 14.54)$ $(\% 1.43, \% 0.95)(\% 72.22, \% 68.52)(\% 70.45, \% 47.20)(\% 53.33, \% 14.70)$ respectively ,The result indicated also that the reclamation of Kharazi Wady sewage was according to WHO standard for irrigation pwposes.
\end{abstract}




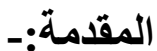

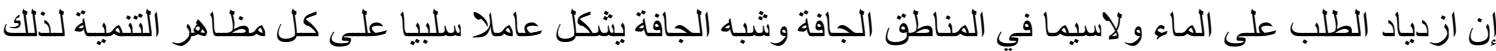

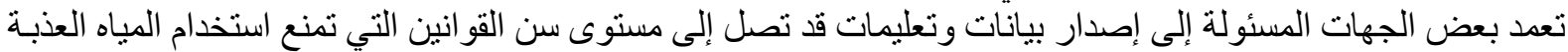

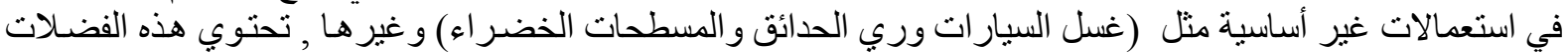

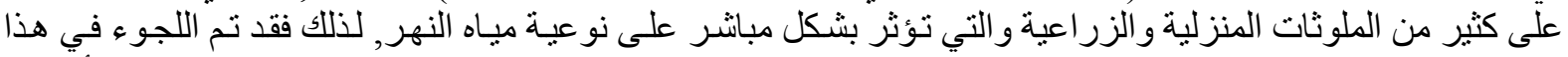

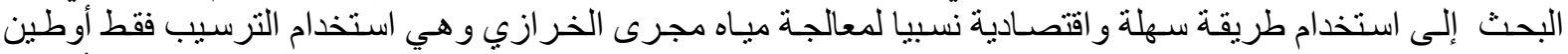

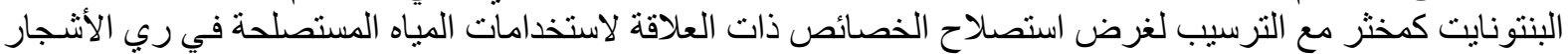

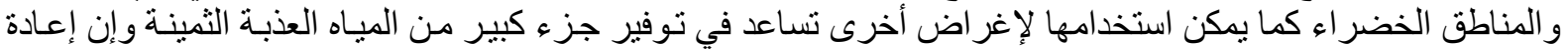

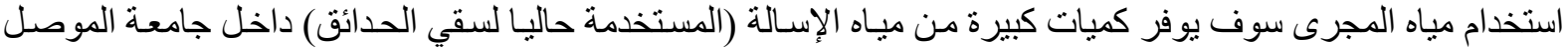

وخارجها.

وقدأشار الباحثنان (Lund and Nessen ,1986) ان إضافة طين البنتونايت إلى المياه الخام يزيل معظم الثو ائب ضمن

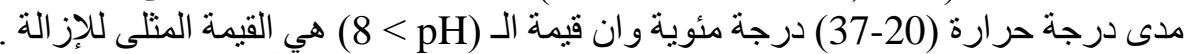

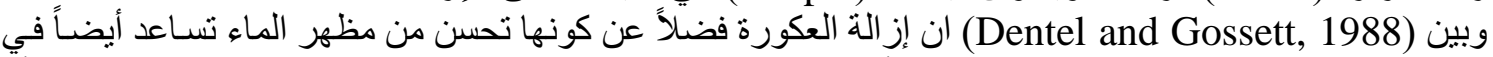

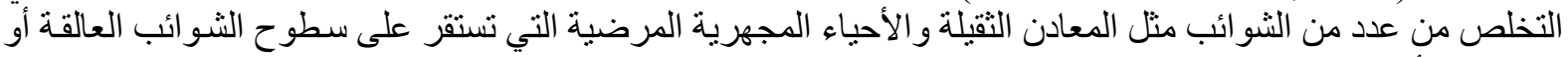

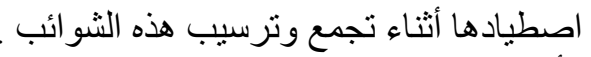

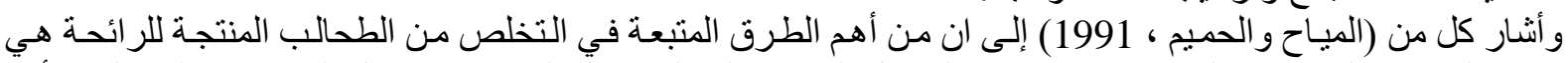

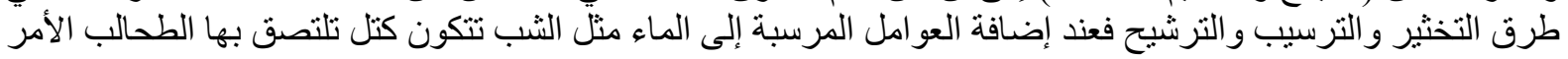
الذي يؤدي في النهاية إلى ترسيبها .

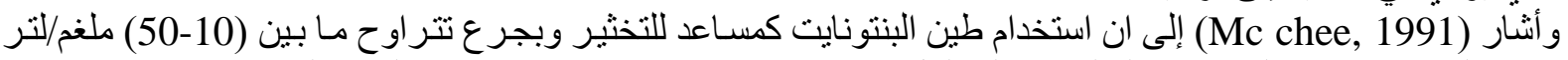

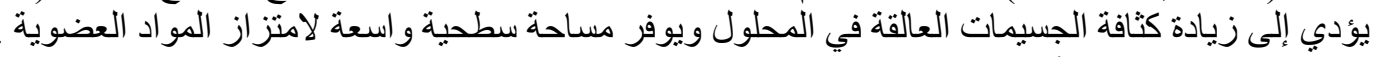

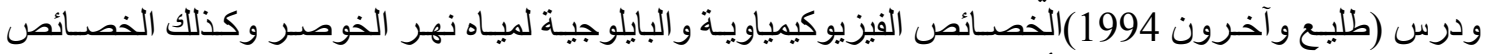

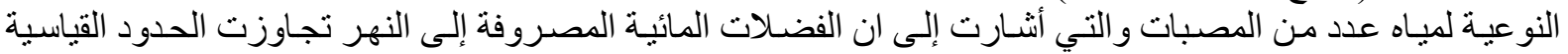

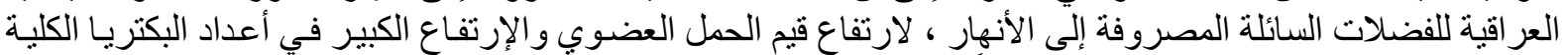

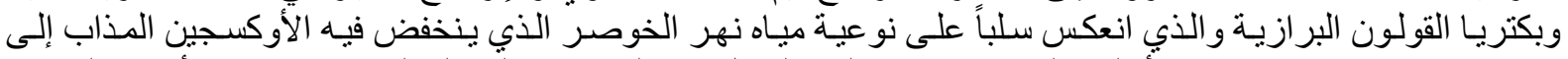

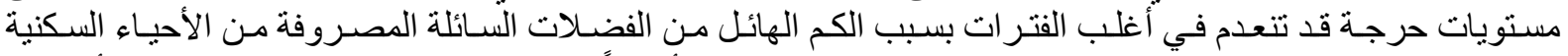

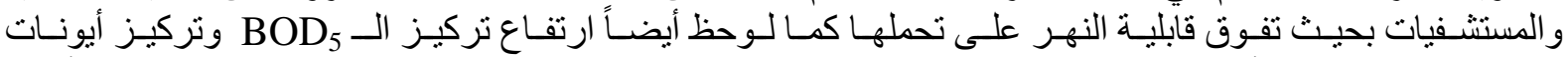
الآورثوفوسفات

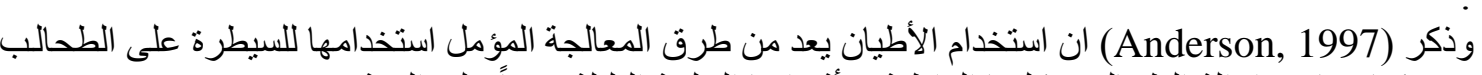

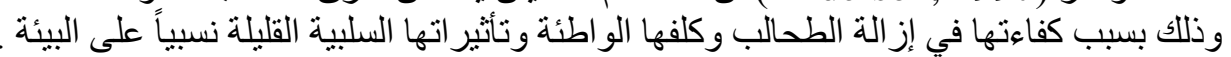

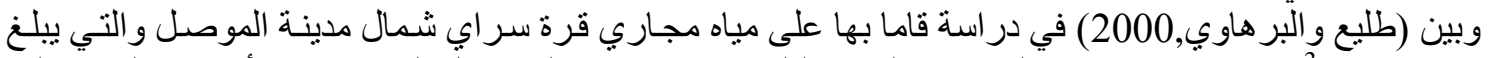

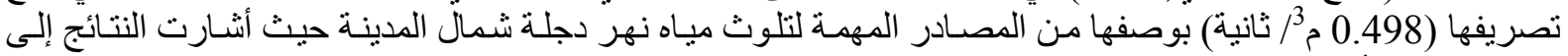

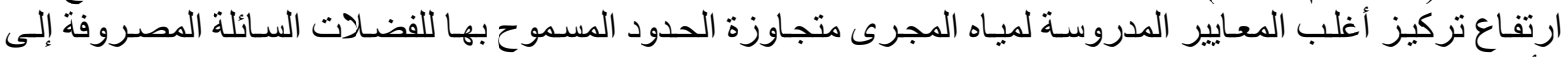

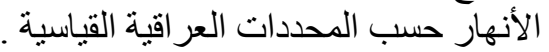

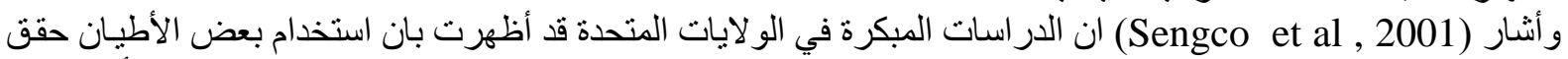

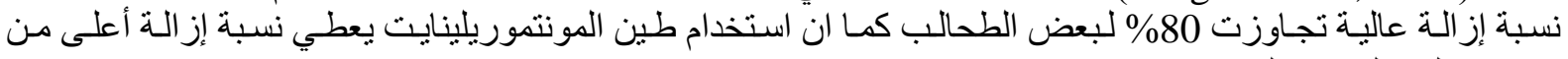

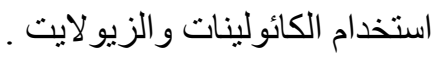

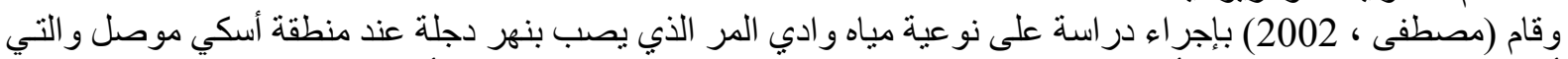

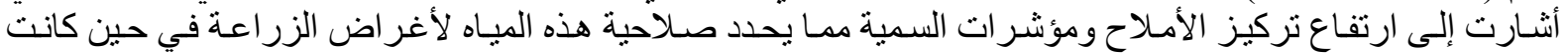

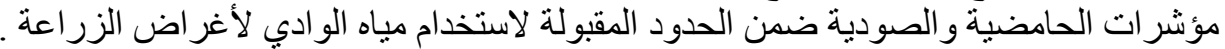

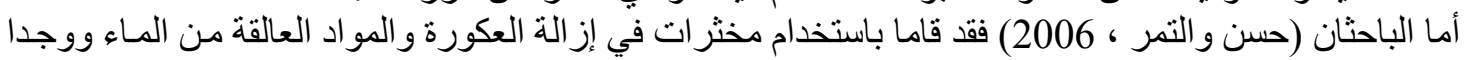

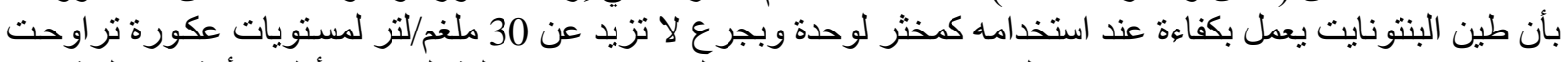

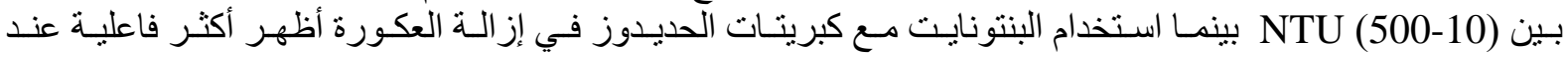

المستويات الواطئة من العكورة الابتدائية .

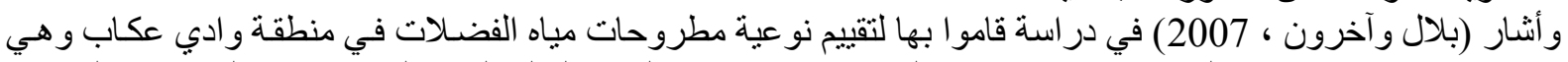

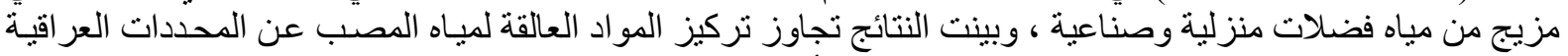

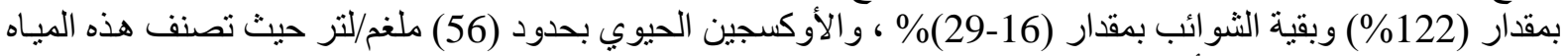

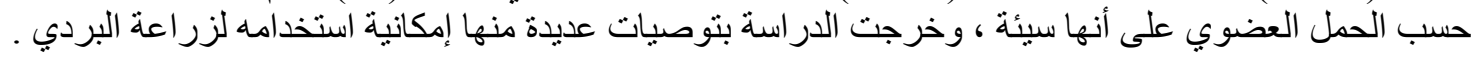




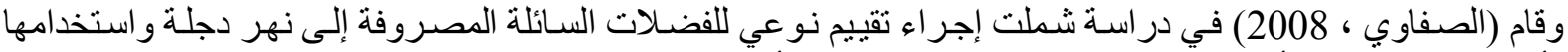

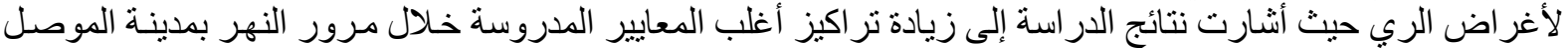

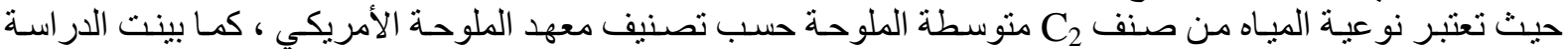

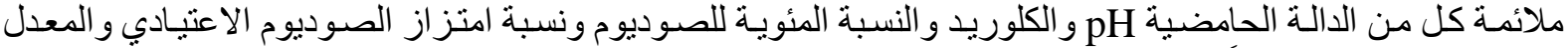

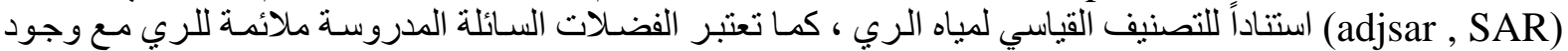
بعض المشاكل المتعلقة بالملوحة و السمية .

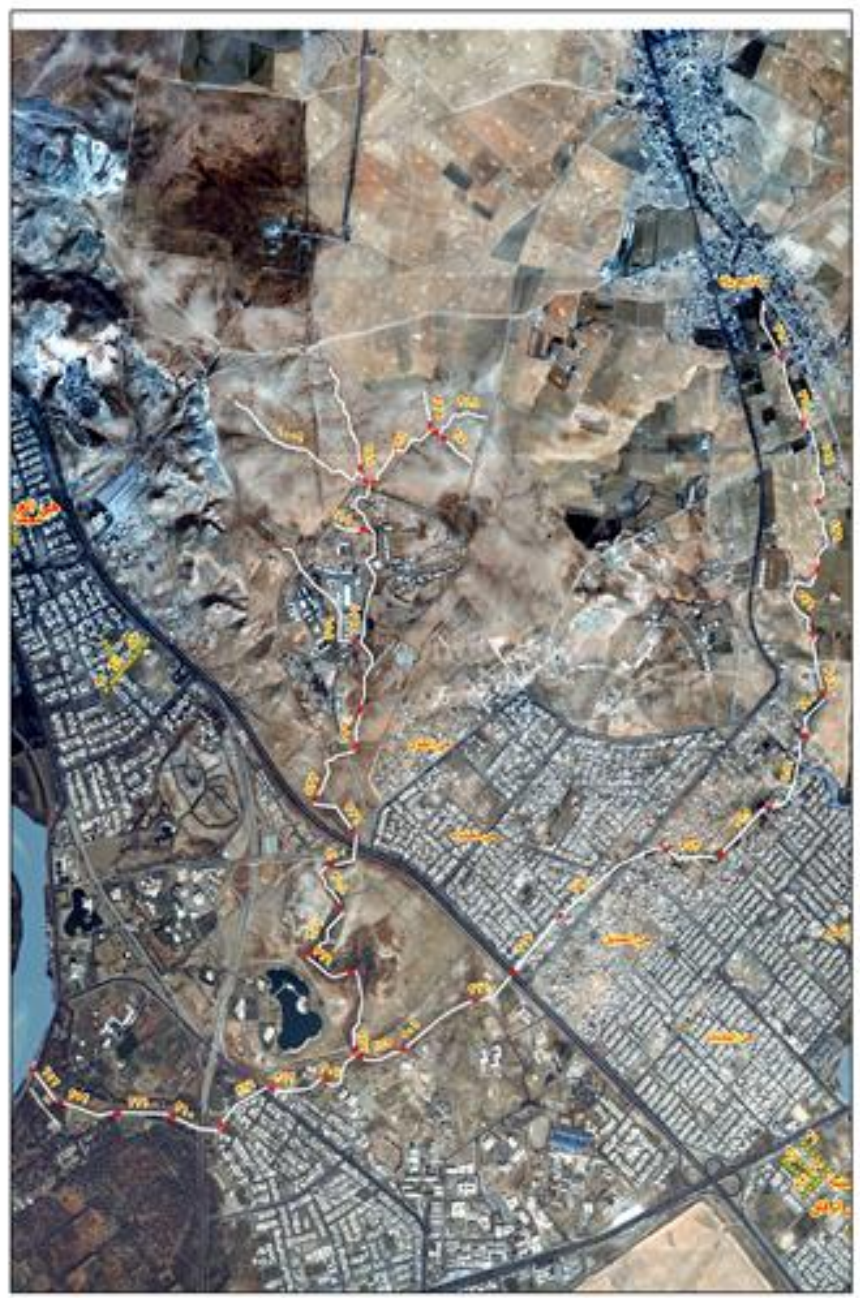

الثشكل (1) : صورة جوية لمسار مجزى الخزازي
حالة دراسبة :-

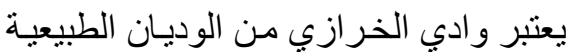

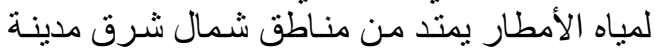

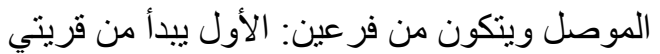

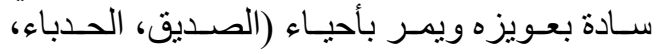

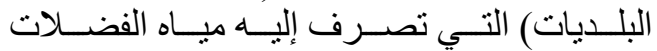

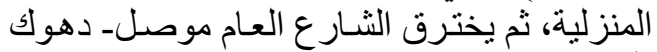

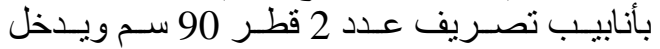
جامعة الموصل قرب بو ابة عمادة الطب البيطري الجديدة ويلغ طوله من منطقة سـادة بعويزه و والى كلى

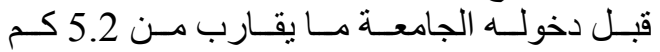

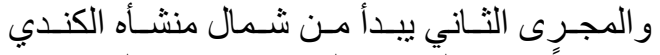

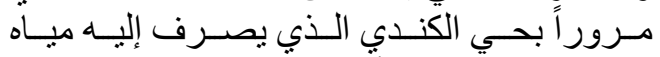

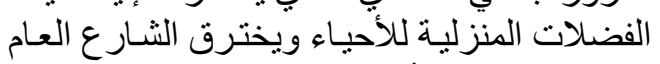

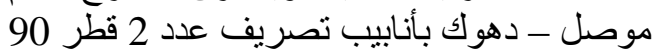

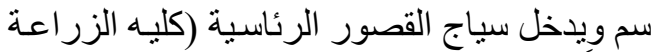

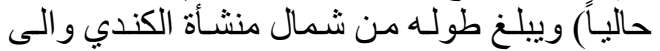
قبل دخول الجامعة ما يقارب 3.2 كم. كم.

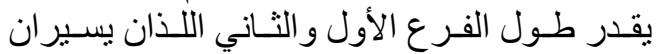

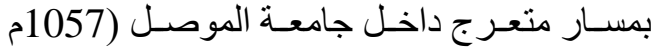

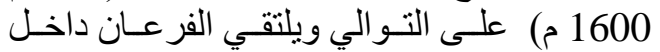
جامعة الموصل قرب بو بوابة كلية الزر اعة الجنو الجنوبي

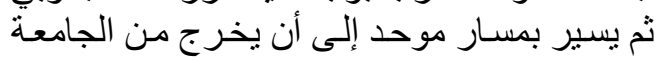

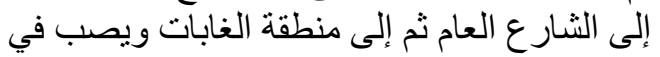

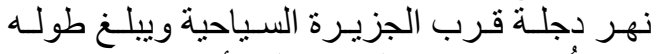

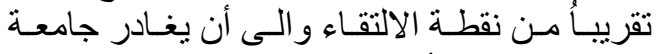

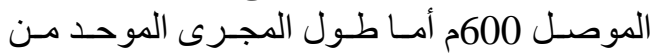

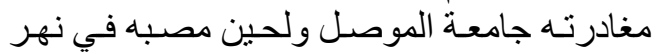

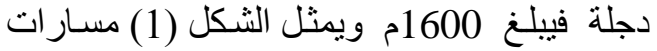

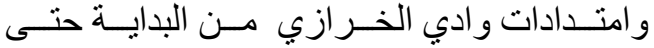

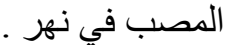

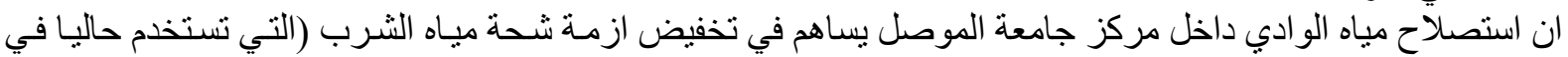

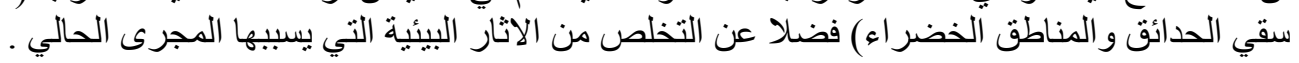

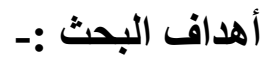

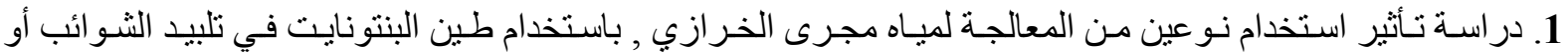

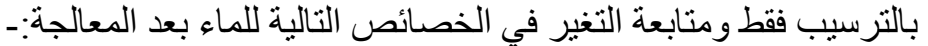

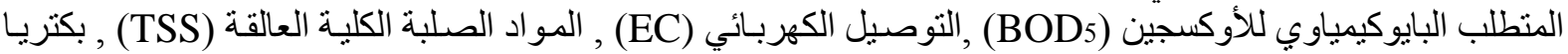

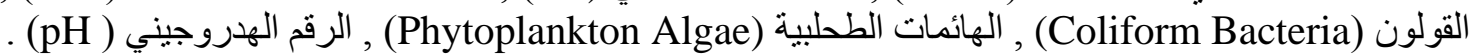

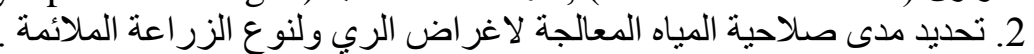
3. تحديد الجرعة المنلى لطين البنتونايت اعتمادا على عكورة الماء النياء الخام. 


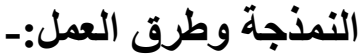

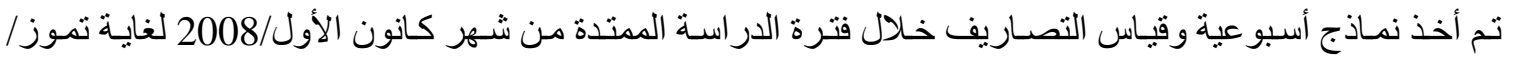

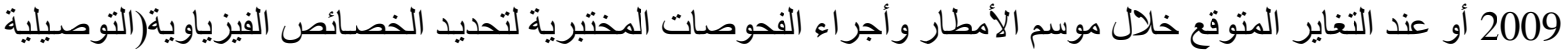

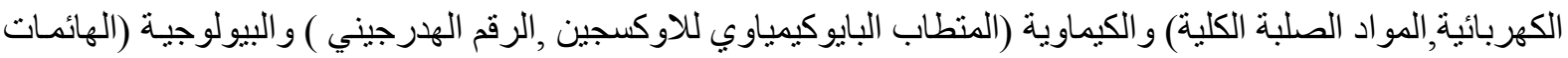

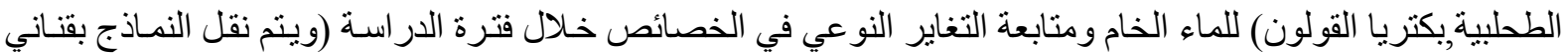

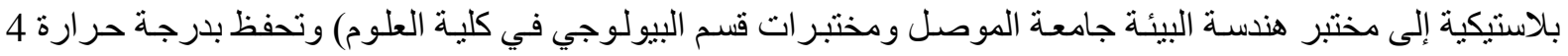

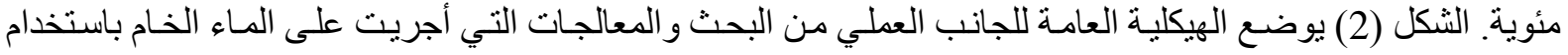

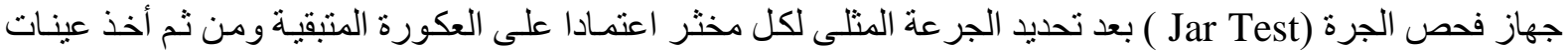
الماء الر ائق لأجر اء فحص الخصائص الفيزياوية و الكيمياوية والبيولوجية.

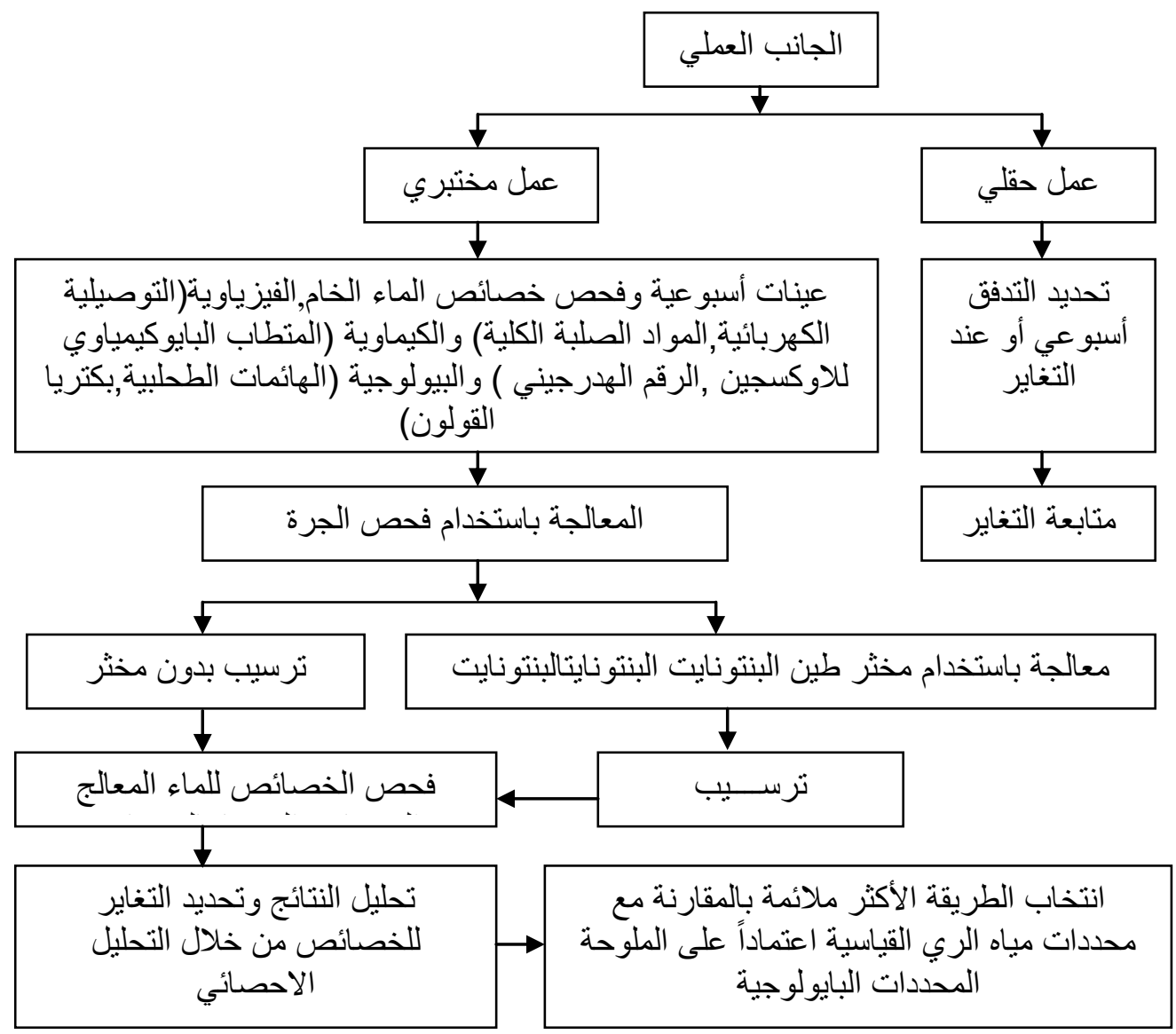

مخطط شكل (2) الهيكلية العامة للجانب العملي من البحث

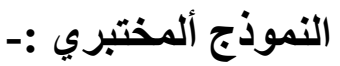

أستخدم جهاز فحص الجرة كنموذج مختبري لتمثيل عملية المعالجة بطريقة التخثير و التلبيد إذ أستخدم طين البنتونايت

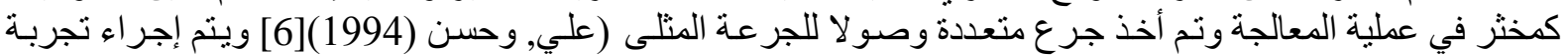

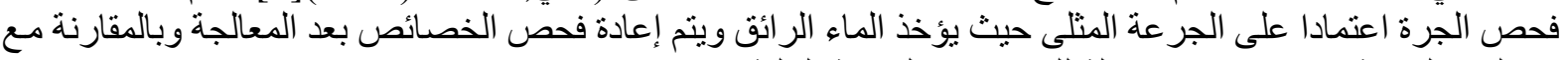

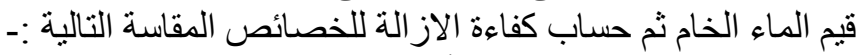

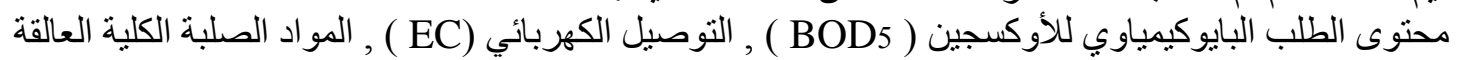

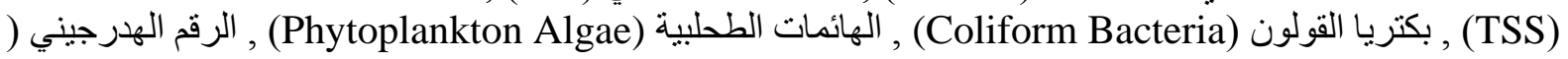


1. قياس المنطلب البايوكيمياوي للاوكسجين (BOD5) حسب الفقرة (507 ) ويدخل ضمنه قياس الاوكسجين المذاب ( ) )

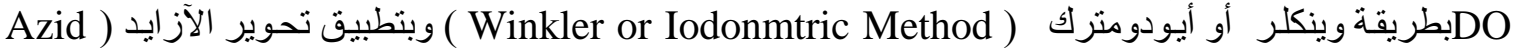

.[13](APHA, AWWA, WPCF (1985)) (Modification 2. قياس كل من الرقم الهيدروجيني (pH) بو اسطة جهاز (pH-meter) وقياس التوصيلية الكهربائية (EC ) و الكدرة

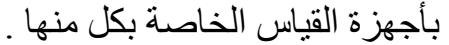

3. قباس المو اد الصلبة الكلية العالقة (TSS) حسب الفقرة ) (1985) (209c) (13).

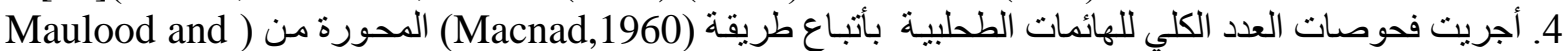

. (Hinton, 1979

5. نم إجر اء فحص بكتريا القولون البرازية بطريقة(Fecal Coliform MPN Procedure) استخدمت طريقة الأنابيب

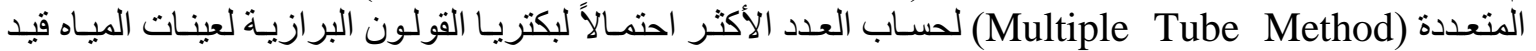

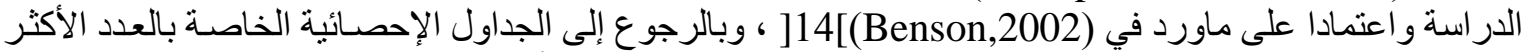
احتمال لبكتريا القولون Most Probable Number (MPN) وتم حساب أعداد بكتريا القولون في(100) مل.

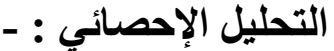

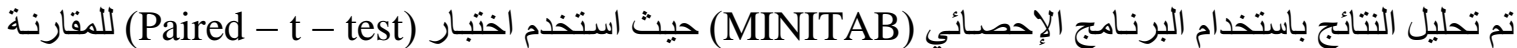

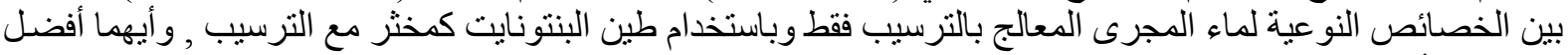

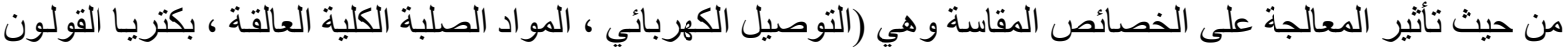

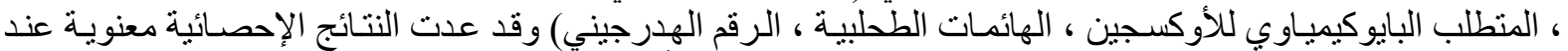

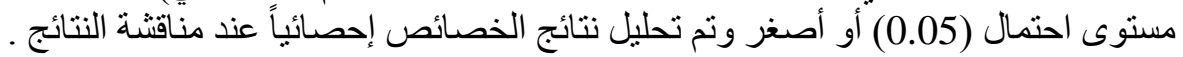

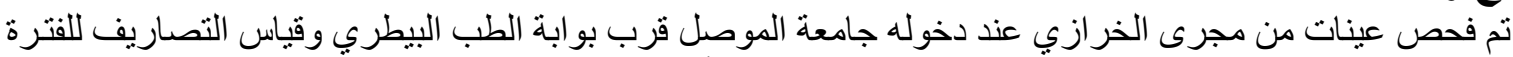

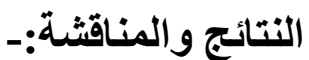

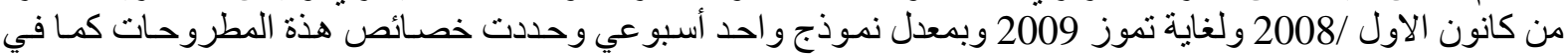

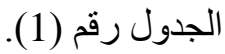

جدول رقم (1) ييين الخصائص المهمة لمطروحات مجرى الخر ازي في مدينة الموصل قبل المعالجة

\begin{tabular}{|c|c|c|}
\hline 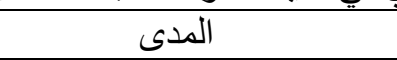 & الخاصية للماء الخام & التسلسل \\
\hline ) (78-35) ملغر ام/ لتر & المتطلب البايوكيمياوي للأوكسجين (BOD5) & 1 \\
\hline (118-54) ملغر ام/ لتر & المو اد الصلبة الكلية العالقة (TSS) & 2 \\
\hline (940-633) مايكروموز/ سم & ـ التوصيل الكهربائي (EC) & 3 \\
\hline ) (280-23) خلية/100مللتزر & بكتريا القولون (Coliform Bacteria) & 4 \\
\hline (160-42) خلية/مللتر & الهائمات الطحلبية Phytoplanktonic) Algae & 5 \\
\hline $\mathrm{pH}(7.75-7.41)$ & الرقم الهدروجيني (pH) & 6 \\
\hline
\end{tabular}

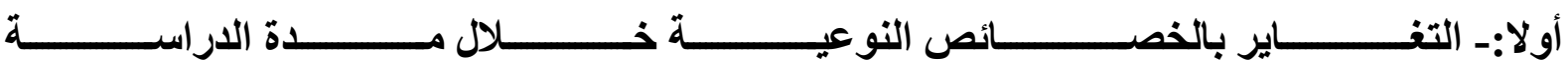

\section{1 ـ التوصيل الكهربائي Electrical Conductivity) EC}

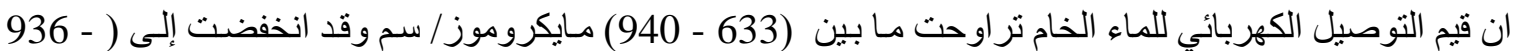

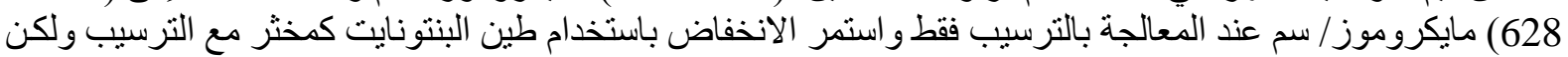

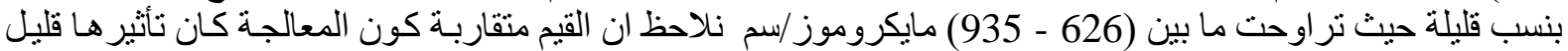

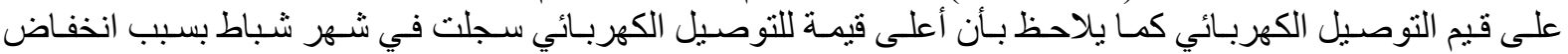

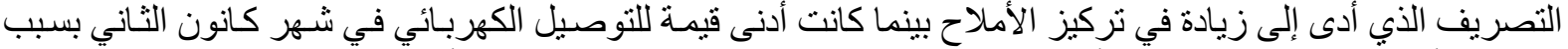

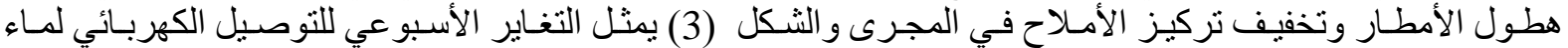

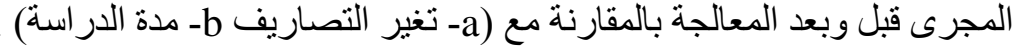




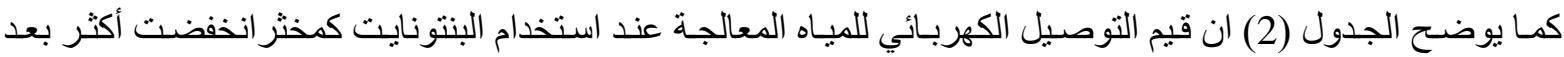
الترسيب مما يدل على وجود فرق معنوي عند مستوى احتمال (2>0.001) ولصنالح الكيال المعالجة بالبنتونايت .
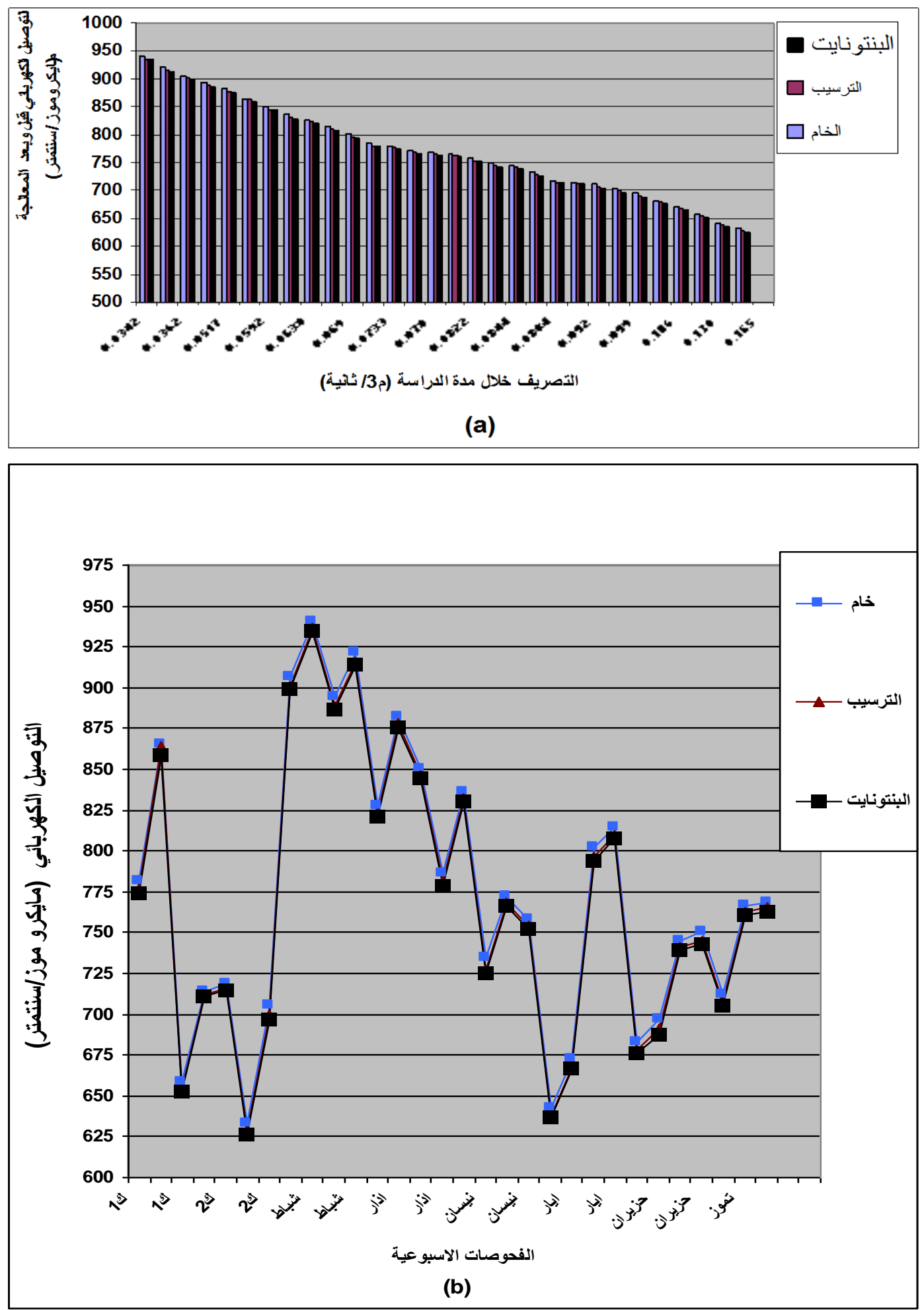

الثكل (3) يمثل التغاير الأسبو عي للتوصيل الكهربائي لماء المجرى قبل التبل

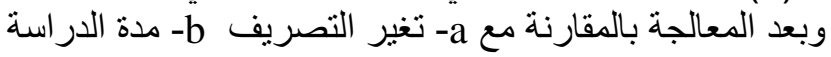


2 Total Suspended Solid (TSS) المواد الصلبة الكلية العالقة

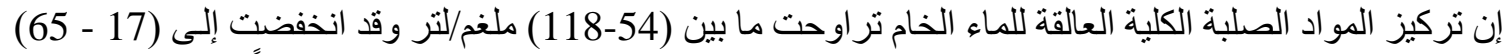

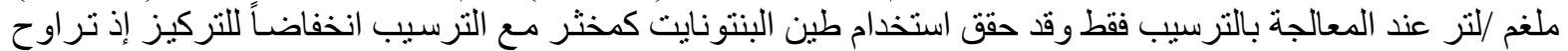

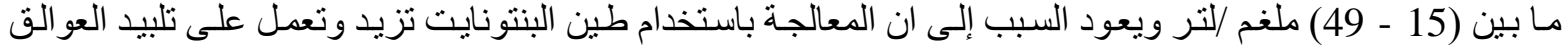

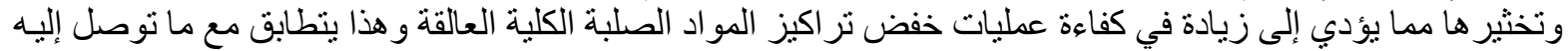

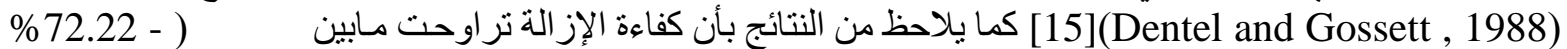

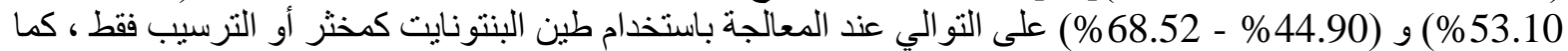

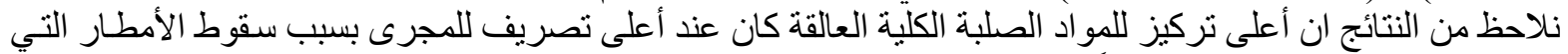

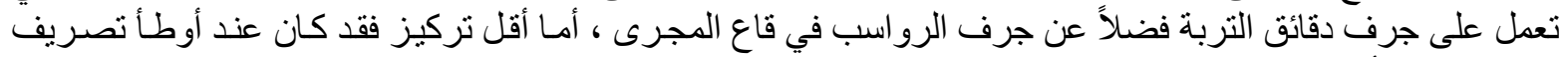

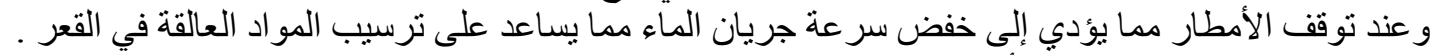

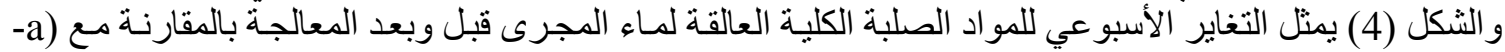

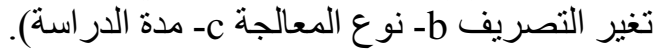
يوضح الجدول (2) ان تركيز المو اد الصلبة الكلية العالقة للمياه المعالجة عند استخدام البنتونايت كانت الكئ أكثر انخفاضـاً منها بعد الترسيب مما يدل على وجود فرق معنوي عند مستوى احتمال (0.001 > p) ولصالح المعالجة بالبنتونايت .

\section{Coliform Bacteria بكتريا القولون}

إن أعداد بكتريا القولون في مياه المجرى بعد الترسيب تراوحت ما بين (20 - 230) (خلية/ 100مللتر) بينما

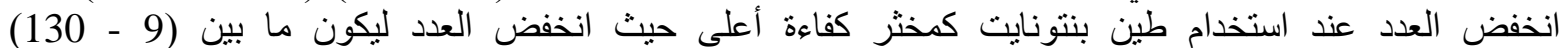

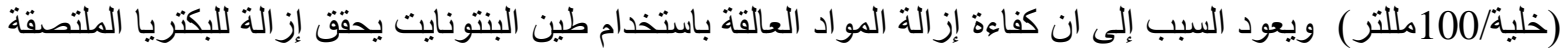

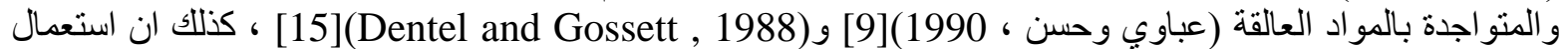

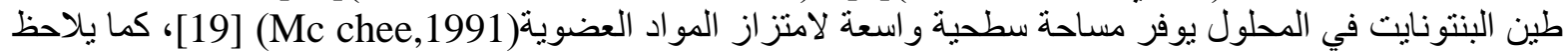

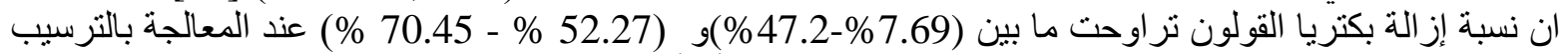
فقط وباستخدام طين البنتونايت كمخثر على التوالي ، كما يلاحظ بأن أعلى قيمة لبكتريا القولون كانت عند

النصريف الادنى للمجرى بيما كانت أقل فيمة عند النصريف الاعلى وهذا ناتج عن النحفيف.

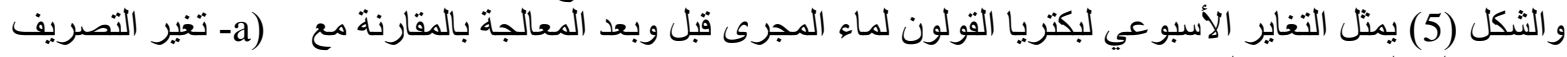

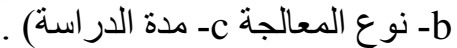

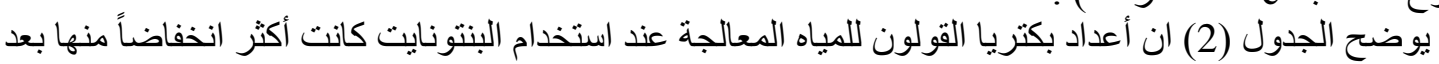
الترسيب مما يدل على وجود فرق معنوي عند مستوى احتمال (20.001 > p p) ولصالح المعالجة بالبنتونايت

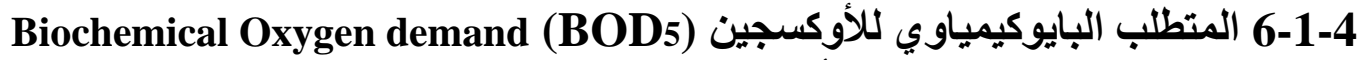

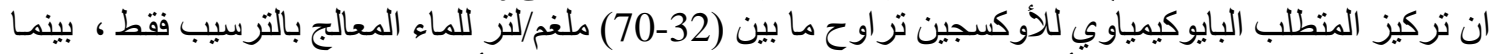

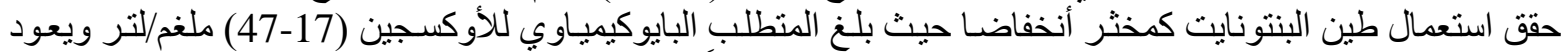

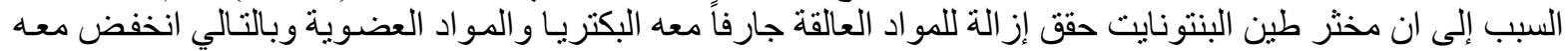

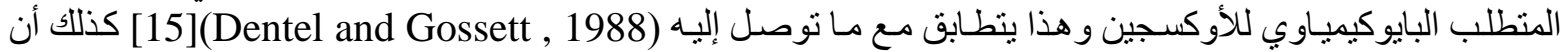

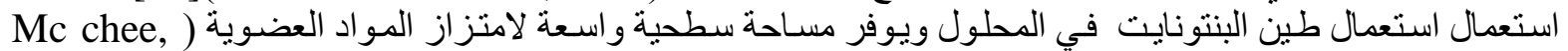

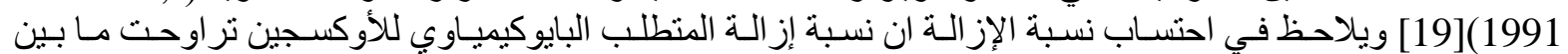

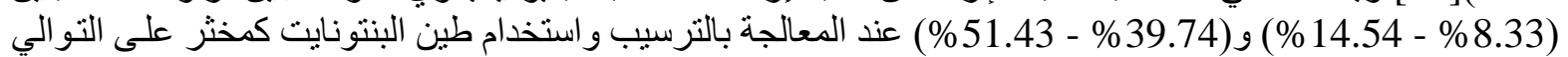

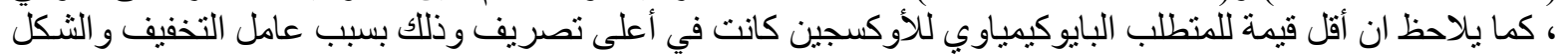

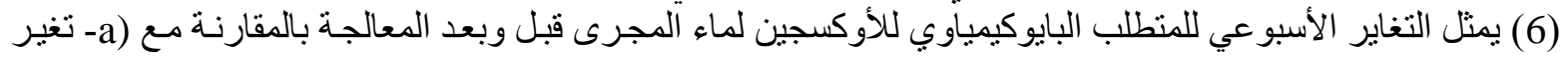

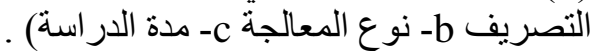

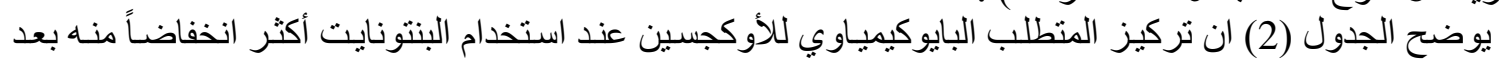

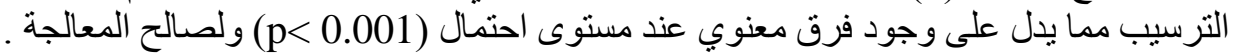



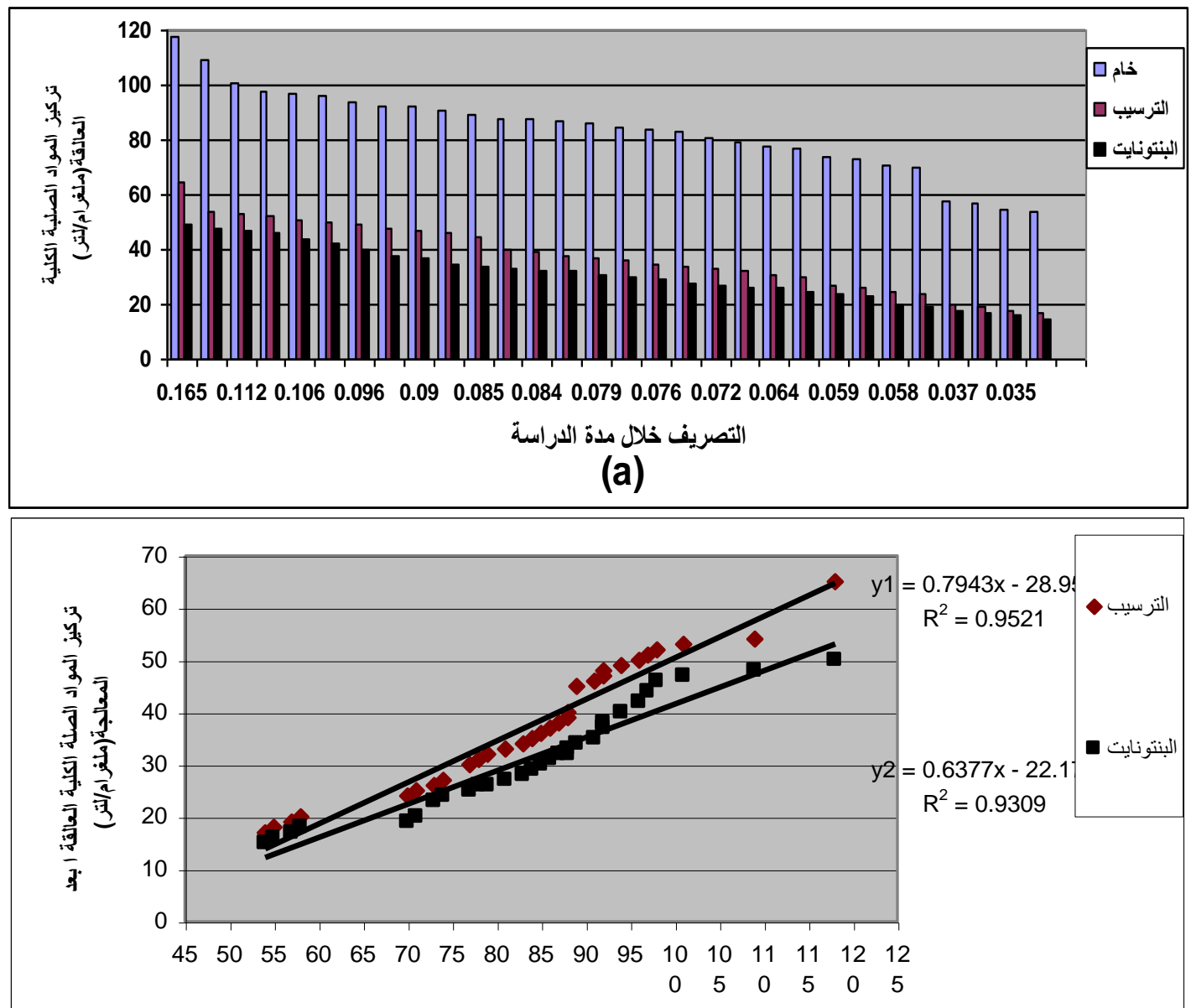

تركيز المواد الصلبة الكلية العالقة قبل المعالجة (ملغرا/تركيز)

(b)

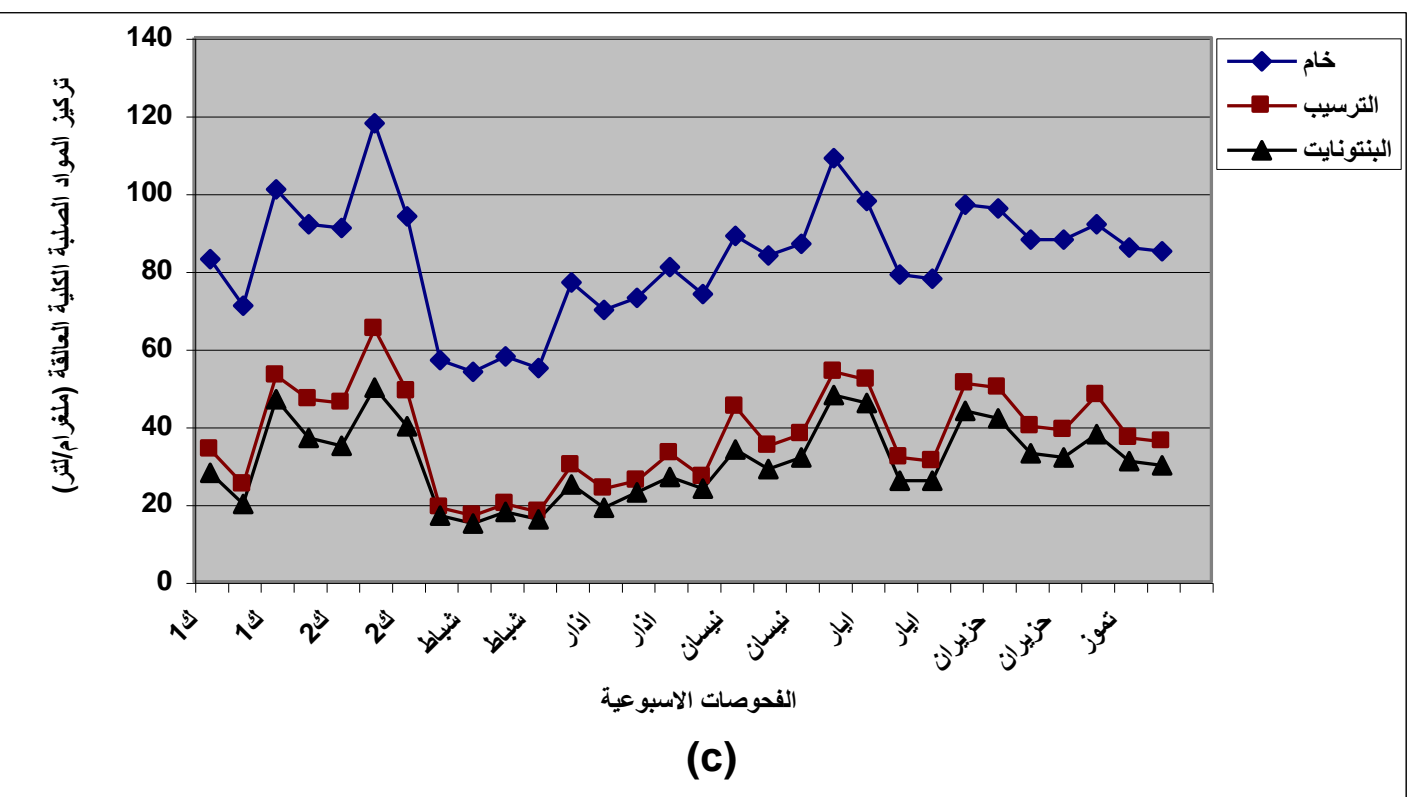

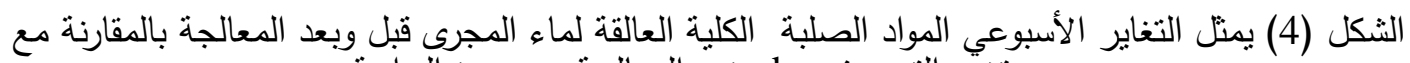

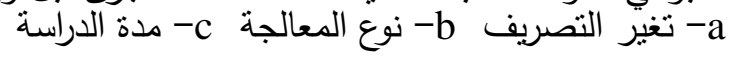


حسن: تعديل خصائص ماء مجرى الخرازي لاستخدامات الري
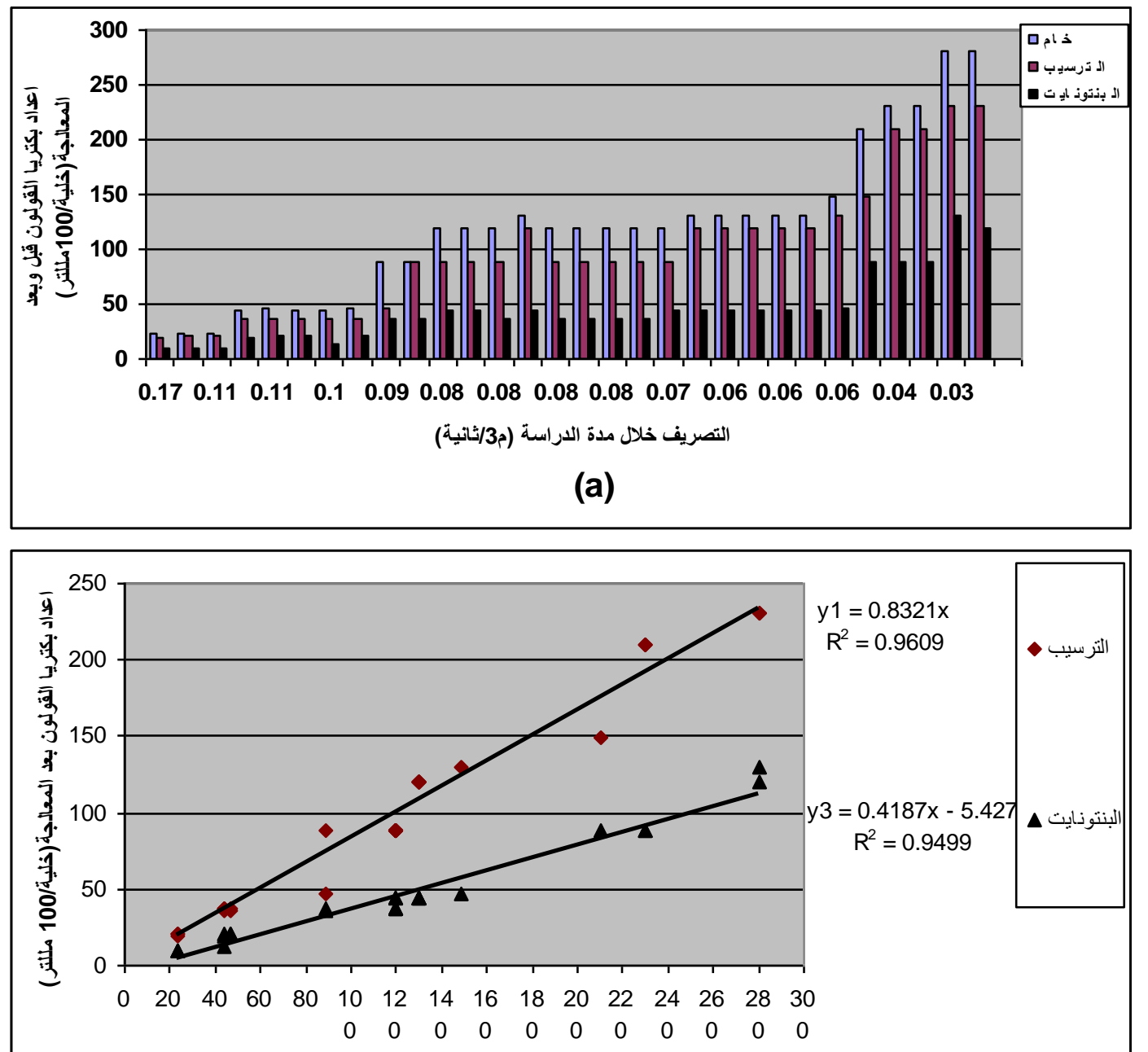

اعاد بكتريا القولون قبل المعالجة(خلية/100 هللتر)

(b)

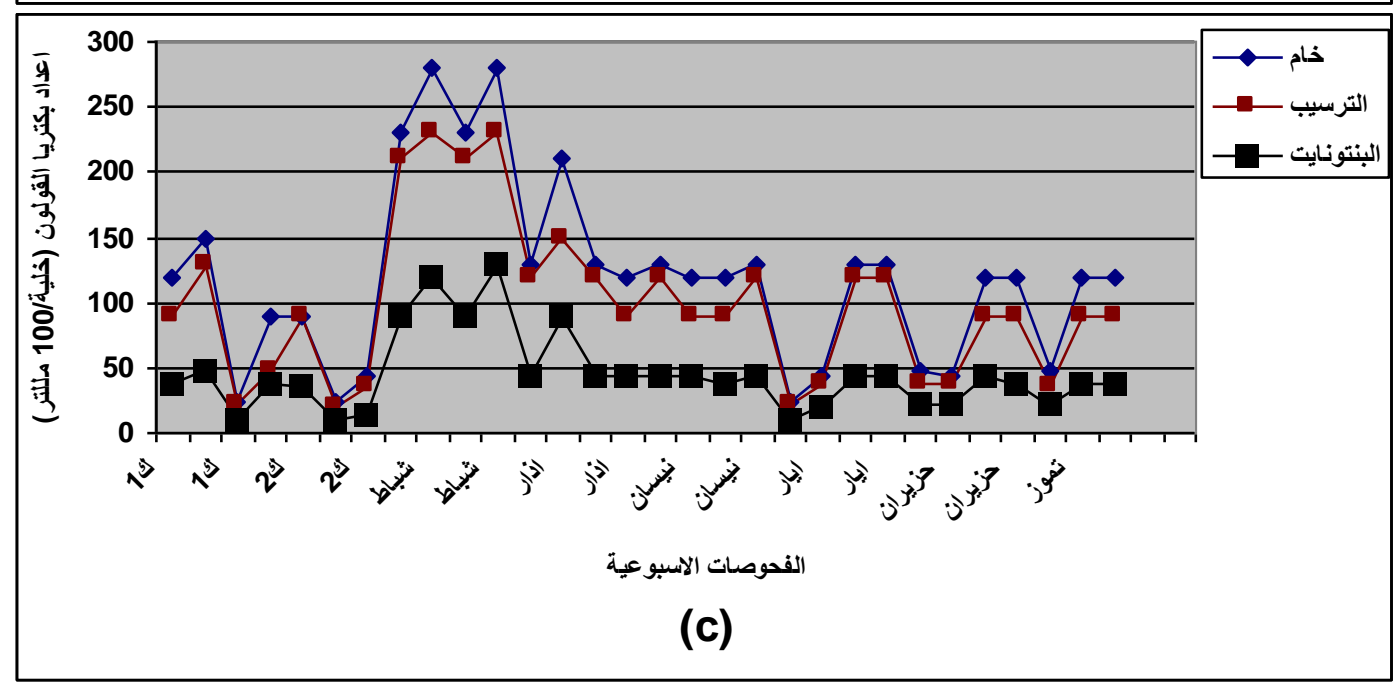

الشكل (5) يمنل التغاير الاسبوعي لبكتريا القولون لماء المجرى قبل وبعد المعالجة بالمقارنة

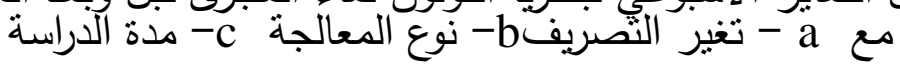




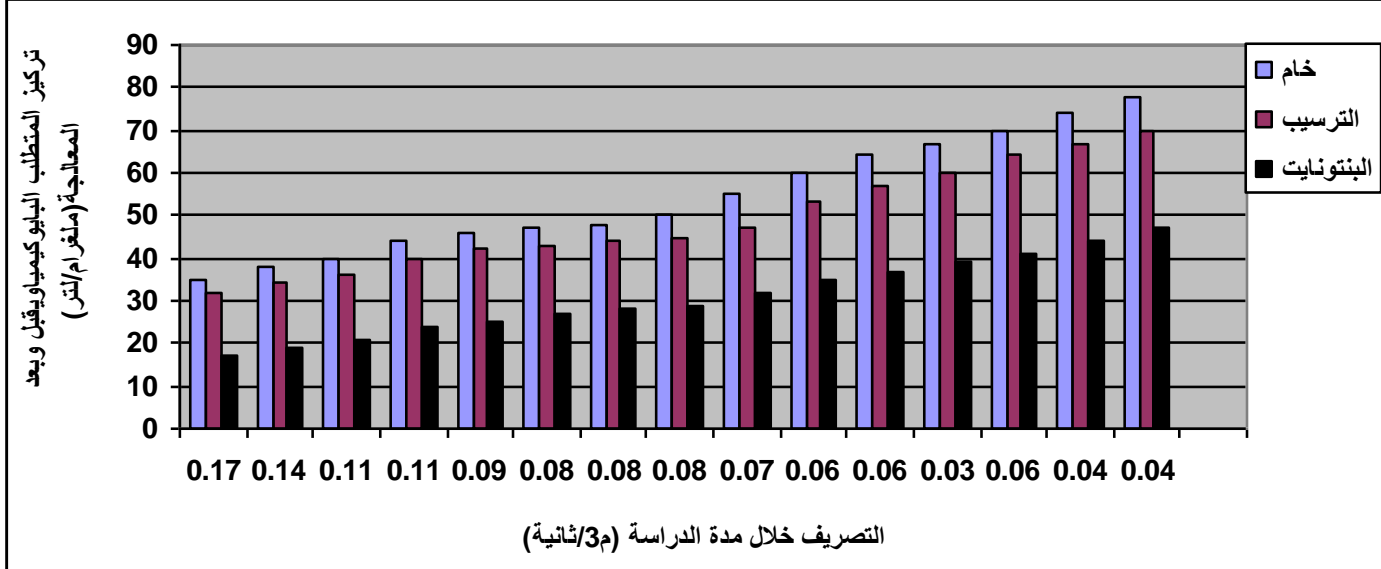

(a)

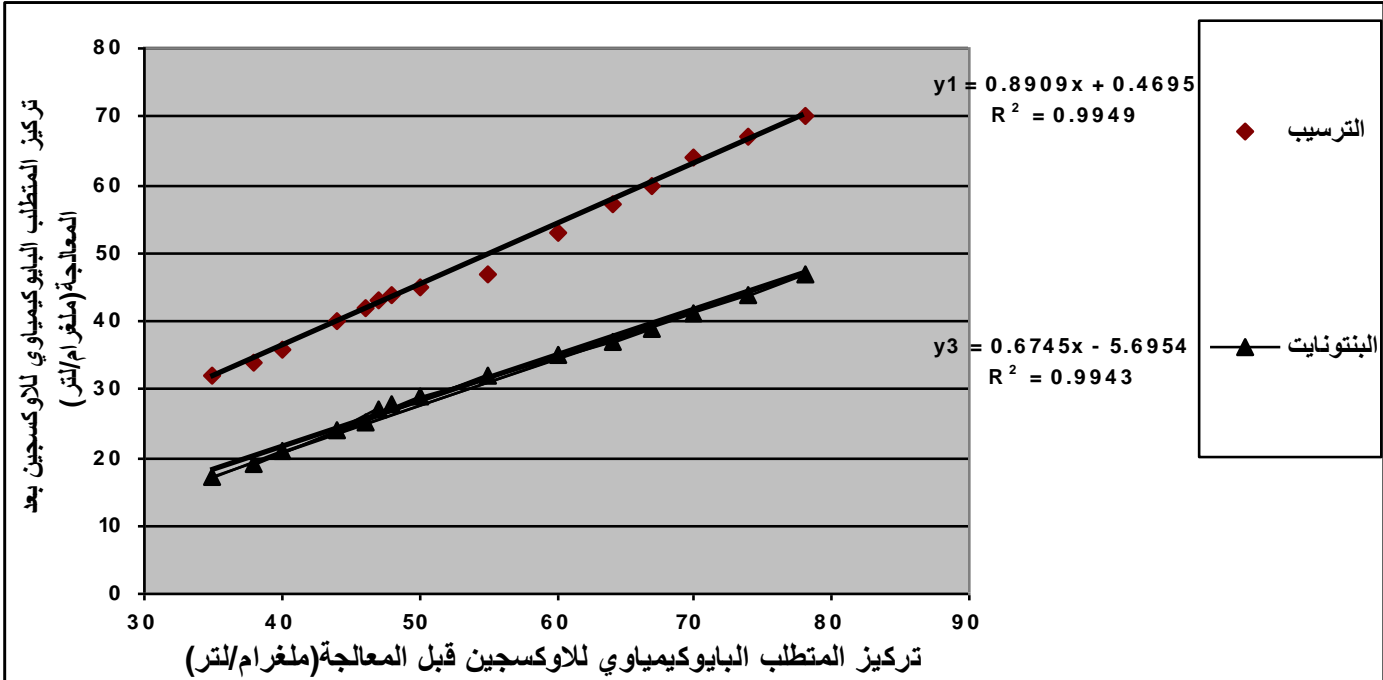

(b)

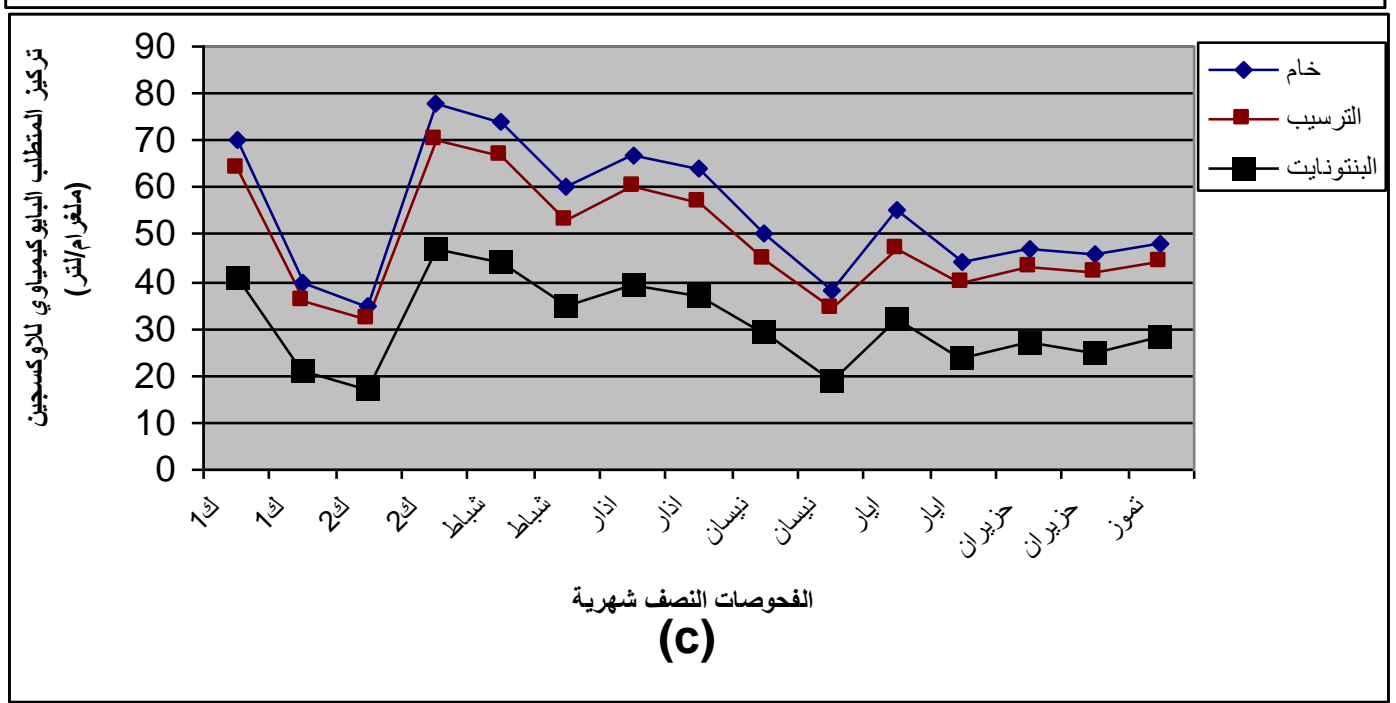

الثكل (6) يمثل التغاير النصف شهري للمتطلب البايوكيمياوي للأوكسجين لماء المجرى قبل وبعد المعالجة بالمقارنة

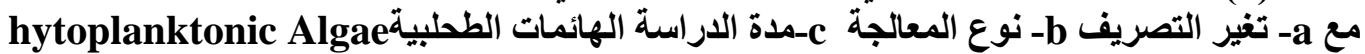



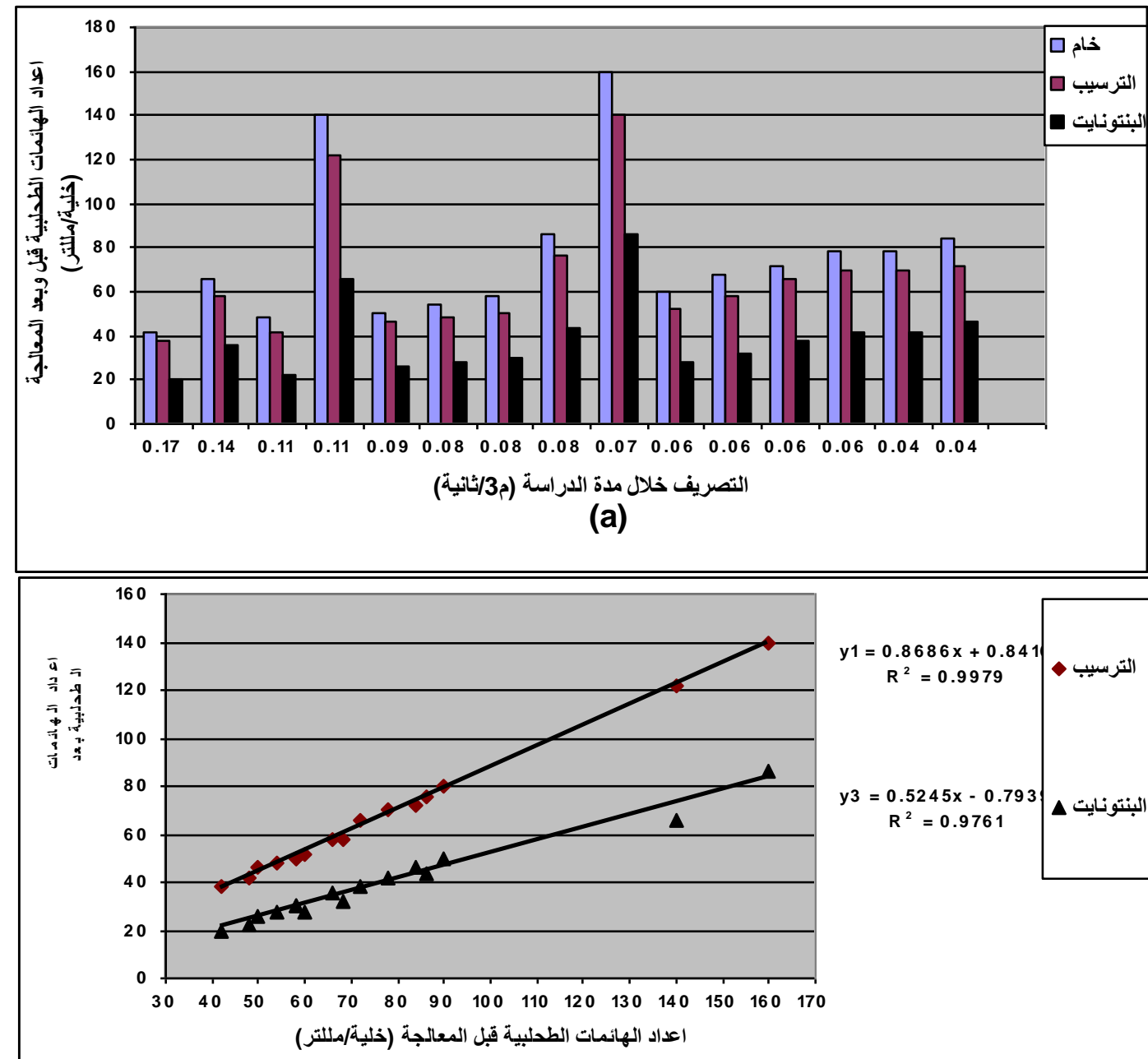

(b)

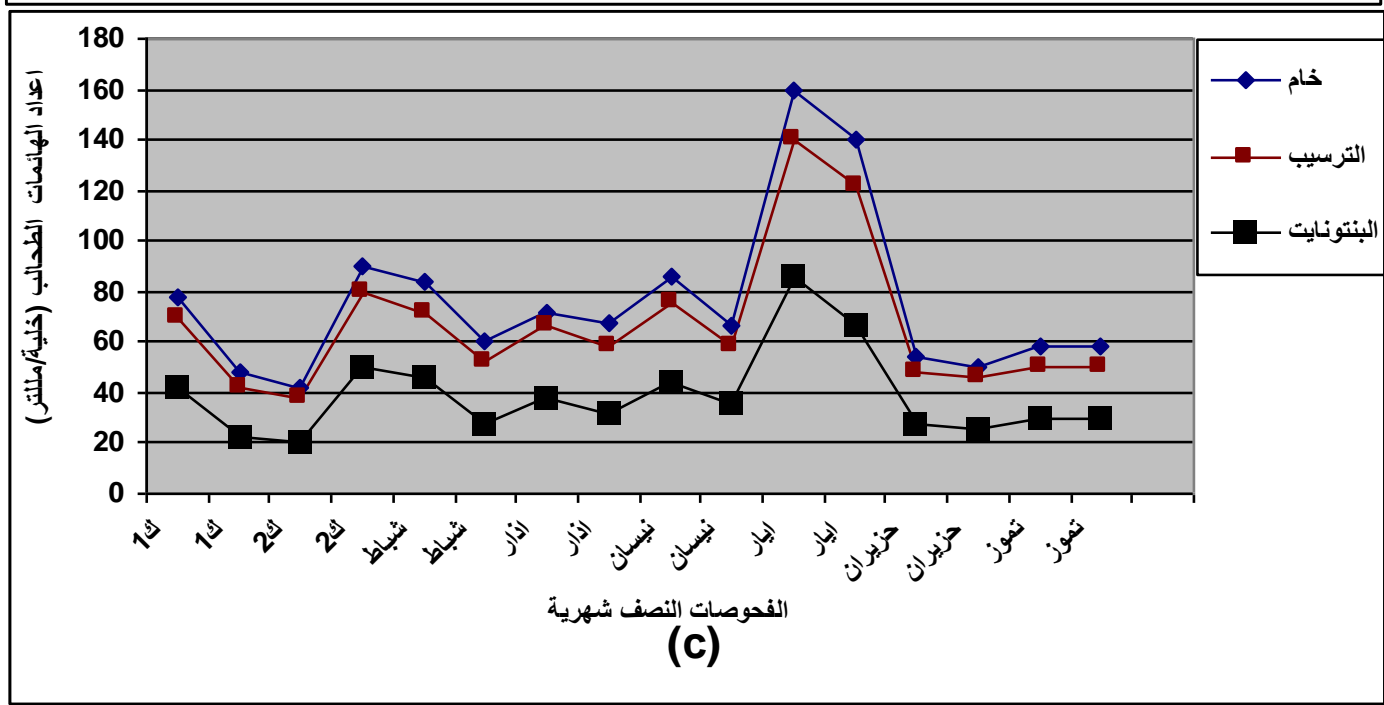

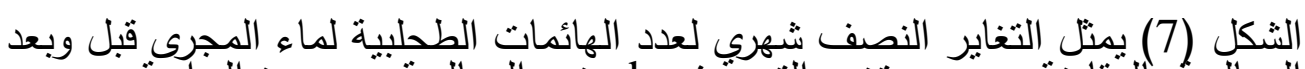

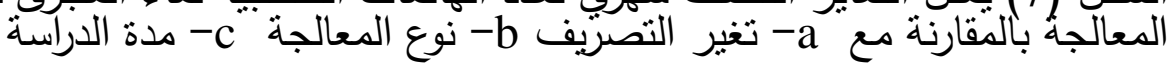




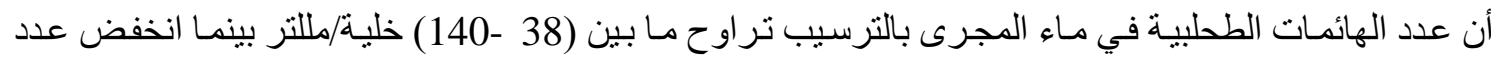

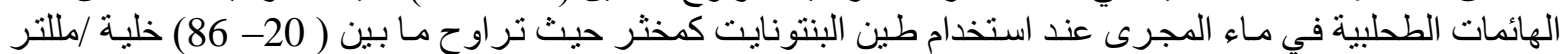
بسبب تكوين طين البنتونايت لبادات تلتصف عليها الطحالب الأمر الذي يؤدي إلى ترسيبها (المياح و الحميم ،

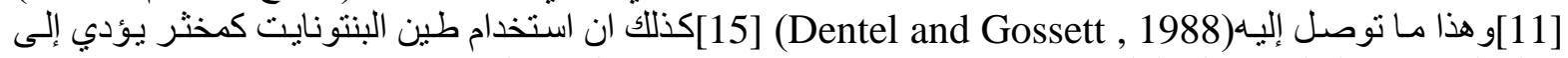

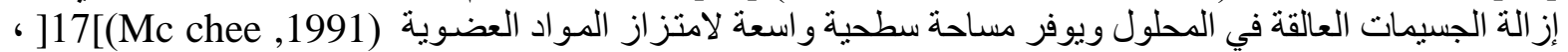

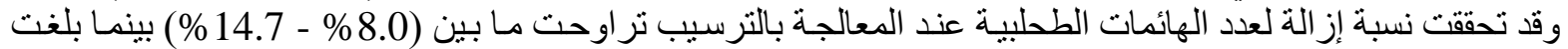

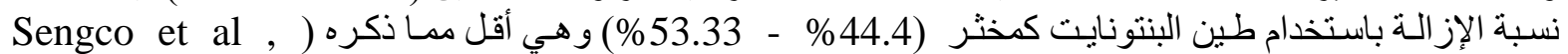

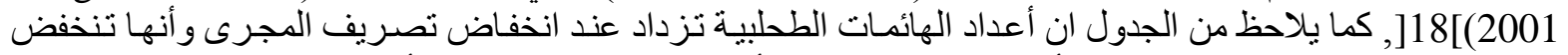

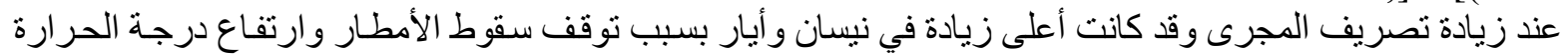

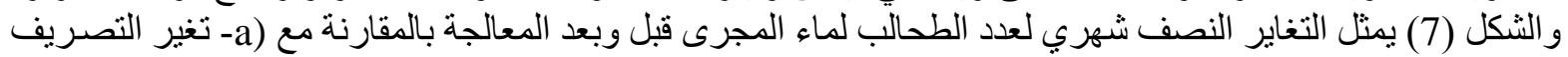

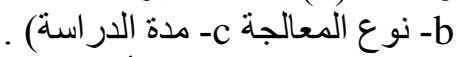

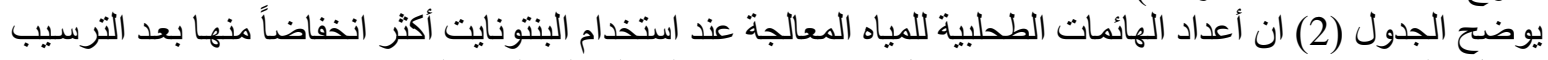
مما يدل على وجود فرق معنوي عند مستوى احتمال (20.001 >0. p) ولصالح المعالجة بالنبتونايت .

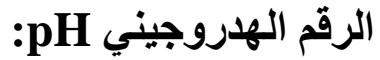

إن تركيز قيم الرقم الهرجيني للماء الخام تراوحت ما بين (7.75-7.41) وقد انخفضت إلى إنى (7.74-7.39) عند

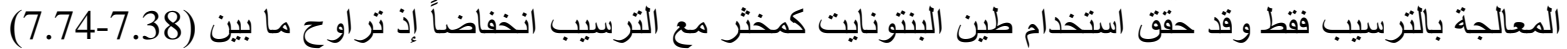

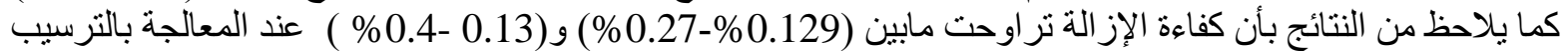
فقط أوطين البنتونايت كمخثر على التوالي كما نلاحظ ان القيم منقاربة كون المعالجة كان تأثير ها قليل على قليم التيم الرقم الثكل (8) يمثل التغاير الأسبوعي للمو اد الصلبة الكلية العالقة لماء الهرى قبل وبعد المعالجة بالمقارنة مع (a- تغير

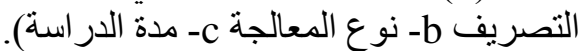
يوضح الجدول (2) ان قيم الرقم الهدرجيني للمياه المعالجة عند استخدام البنتونايت كانت أكثر انخفاضـاً منها بعد الترسيب

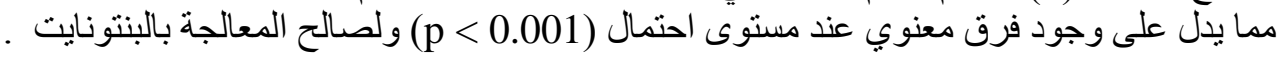

ثانيا:- تعديد مدى صلاحية المياه المعالجة للري ونوع الزراعة الملائمة

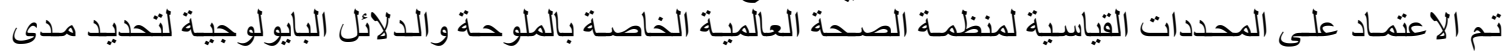

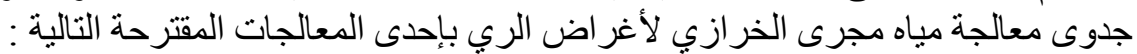

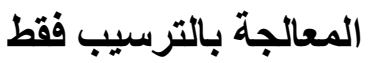

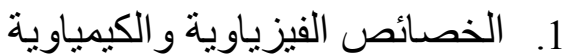

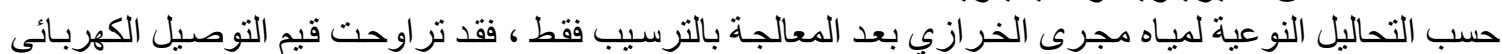

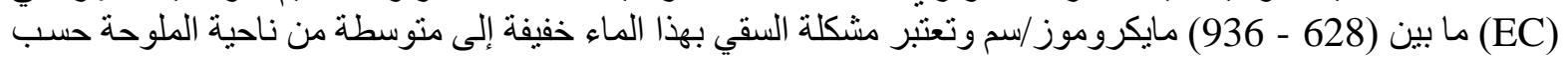

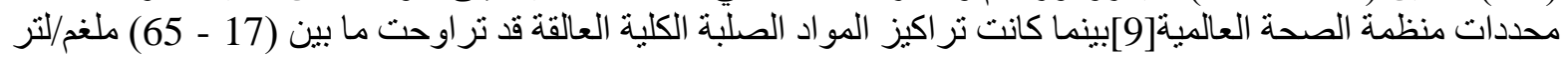

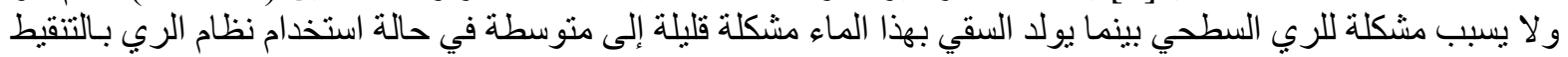

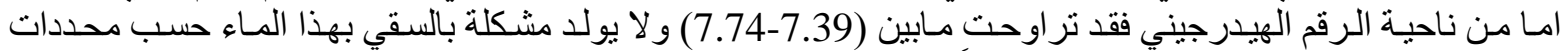

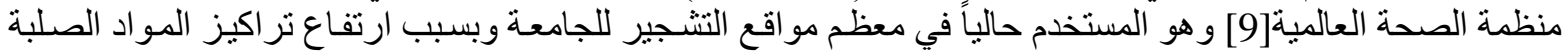
الكلية العالقة عليه لا نوصي باستخدامه.

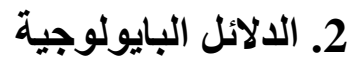

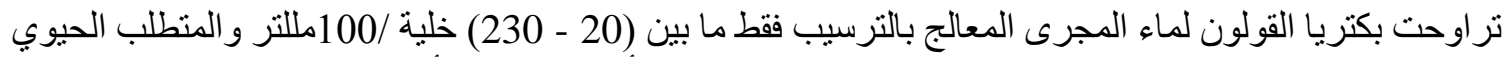

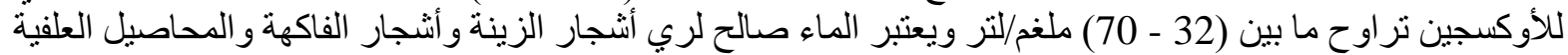

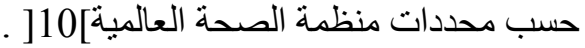


حسن: تعديل خصائص ماء مجرى الخرازي لاستخدامات الري

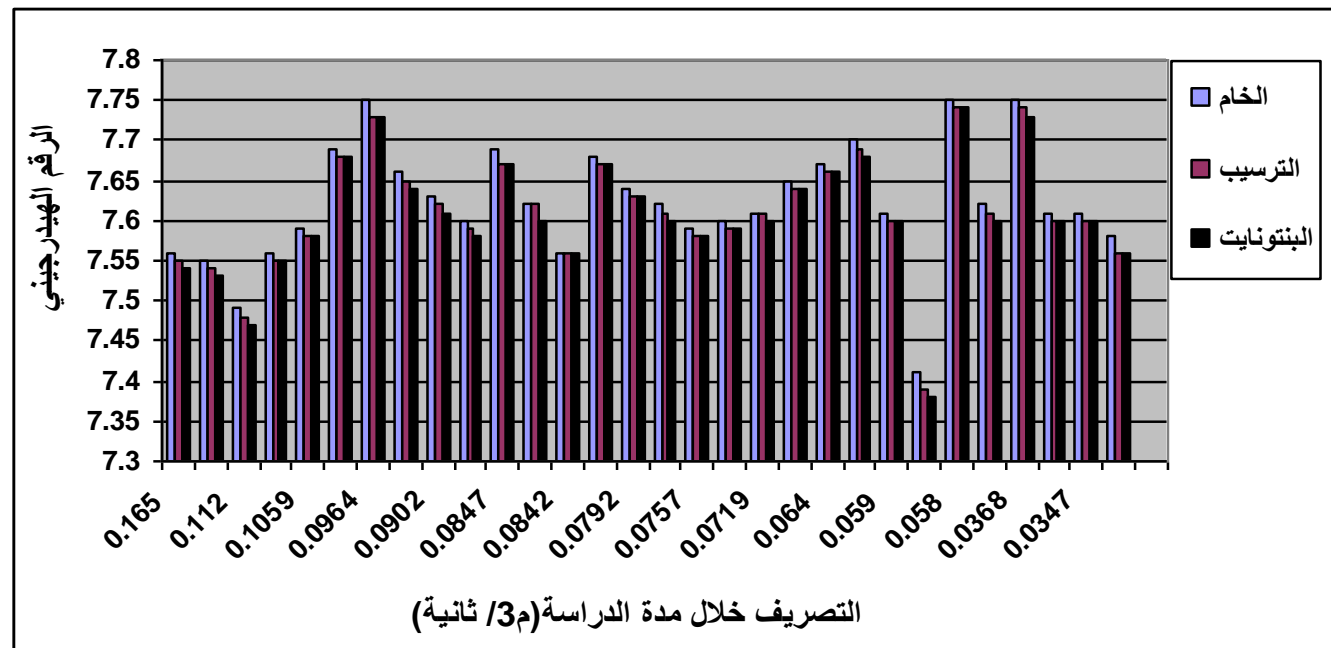

(a)
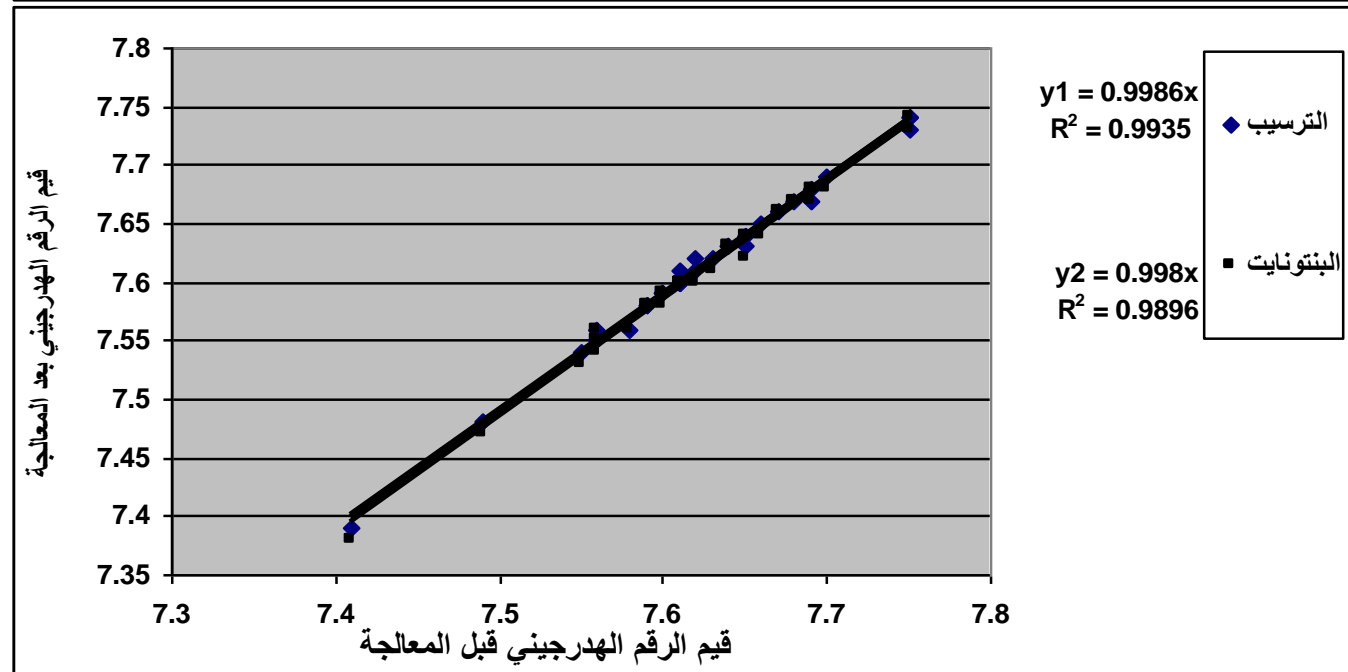

(b)

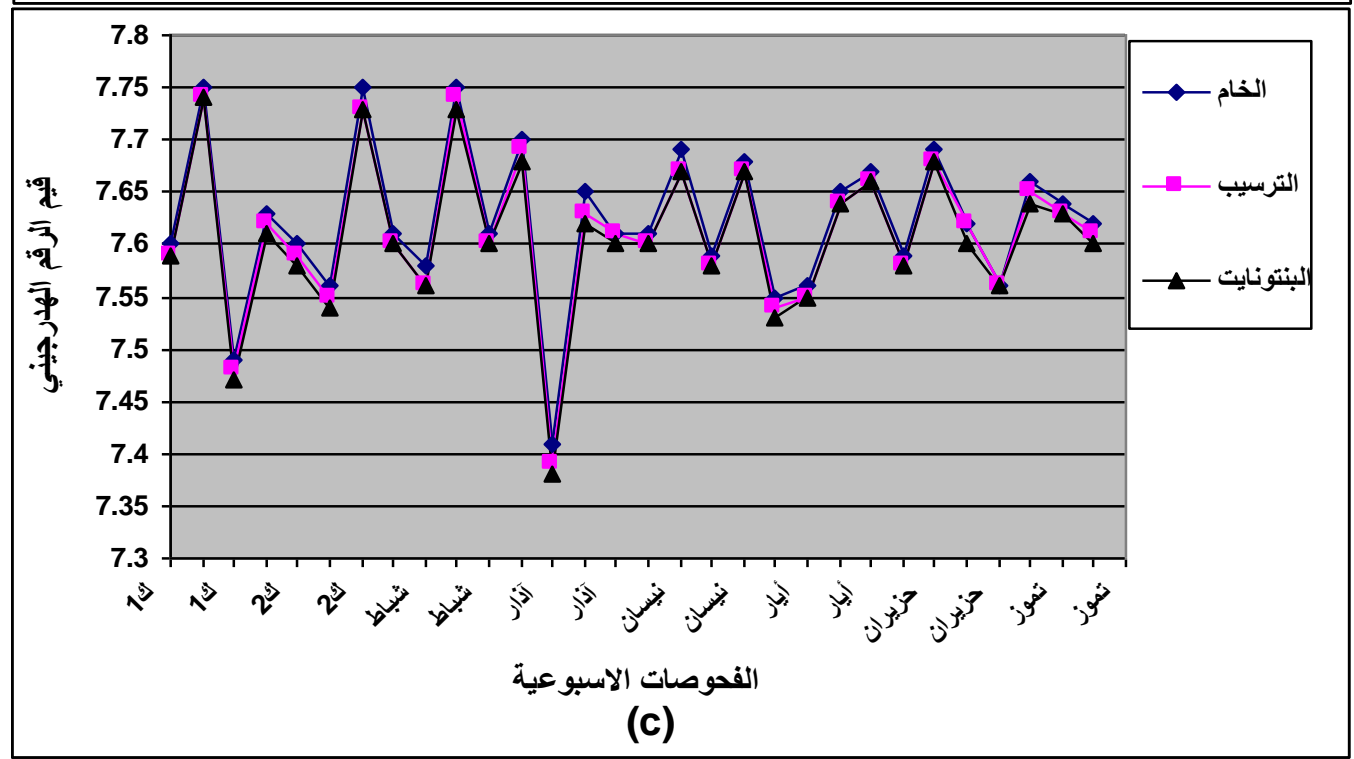

الثكل (8) يمنل التغاير الاسبوعي للرقم الهروجيني لماء المجرى قبل وبعد المعالجة بالمقارنة مع

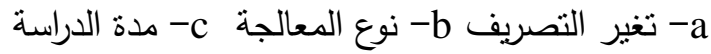




\section{المعالجة باستخدام طين البنتونايت كمخثر مع الترسيب}

\section{1. الخصائص الفيزياوية والكيمياوية}

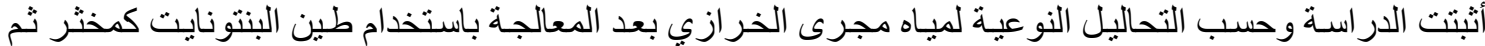

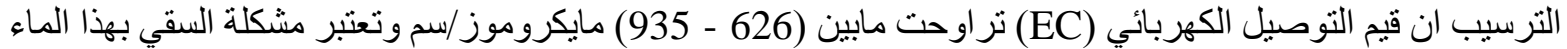

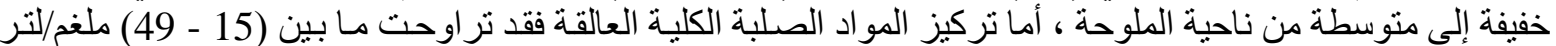

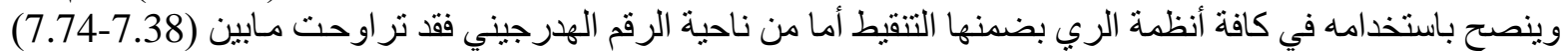
و لايولا مشكلة بالسقي بهذا الماء وحسب محددات منظمة الصحة العالمية] [9] ـ

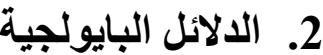

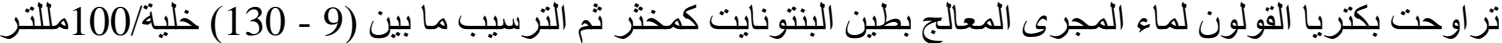

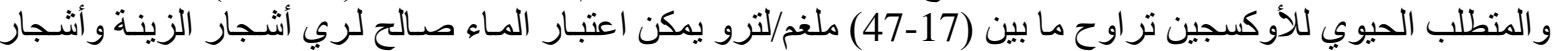

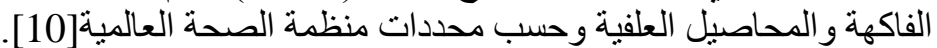

جدول(2)مقارنة إحصائية لخصائص ماء مجرى الخرازي المعالجة عند استخدام البنتونايت كمخثر وبالترسيب فقط

\begin{tabular}{|c|c|c|c|c|}
\hline \multirow{2}{*}{ المعنوية } & \multicolumn{2}{|c|}{ المعدل + الانحر اف المعياري } & \multirow{2}{*}{ الخاصية } & \multirow{2}{*}{ ت } \\
\hline & بنتونايت (الجر عة المثلى) & ترسيب فقط & & \\
\hline 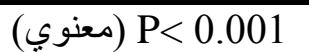 & $85+768$ & $85.2+770.1$ & التوصبل الكهربائي & 1 \\
\hline (معنوي) P< 0.001 & $10.04+31.03$ & $12.44+37.37$ & المو اد الصلبة العالقة الكلية & 2 \\
\hline Pعن P 0.001 (معوي) & $30.20+44.70$ & $60.60+99.10$ & بكتريا القولون & 3 \\
\hline Pعنوي) P>0.001 (معي) & $9.24+31.00$ & $12.20+48.93$ & المتطلب البايوكيمياوي & 4 \\
\hline Pعن P> 0.001 (معوي) & $17.60+39.60$ & $28.75+67.87$ & الهائمات الطحلبية & 5 \\
\hline Pعن P 0.001 (معوي) & $0.0751+7.6073$ & $0.0738+7.6120$ & الرقم الهدرجيني & 6 \\
\hline
\end{tabular}

\section{الاستتتاجات والتوصيات أهم الاستتتاجات التي يمكن استخلاصهات من البحث :}

1. لا تصلح مياه مجرى الخر ازي الخام للاستخدامات المباشرة لأغر اض الري بسبب ارتفاع المو اد الصلبة الكلية العالقـة

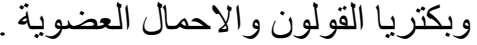

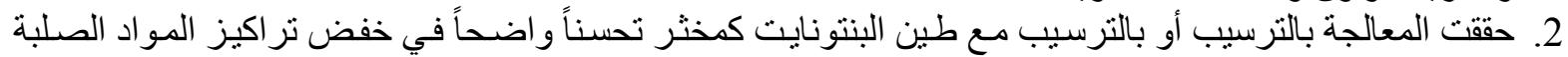

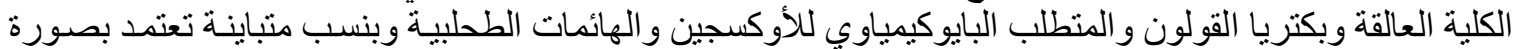

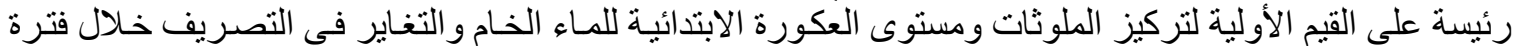

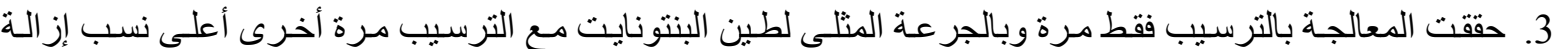

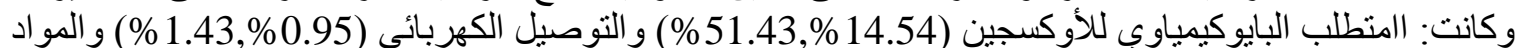

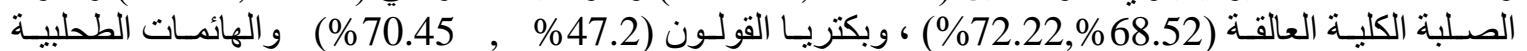

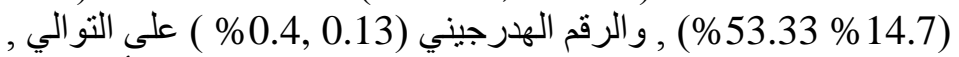

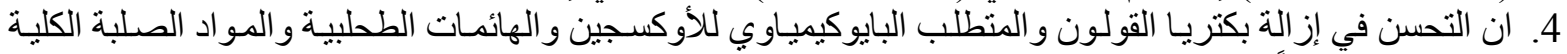

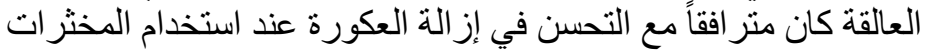

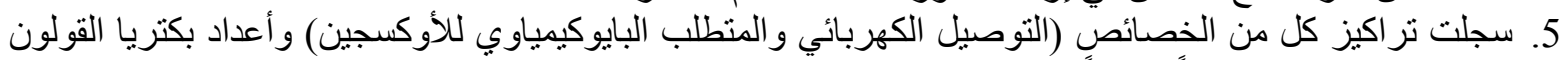

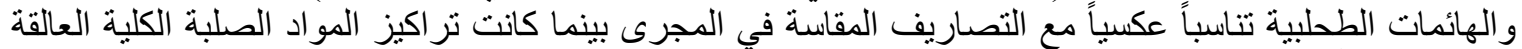

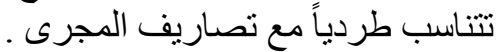


6. أظهرت المقارنة الإحصائية لخصائص المياه المعالجة باستخدام طين البنتونايت كمختر و الترسيب فقط وجود فرق

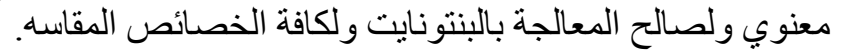

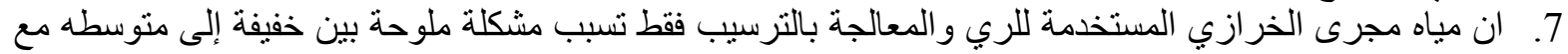

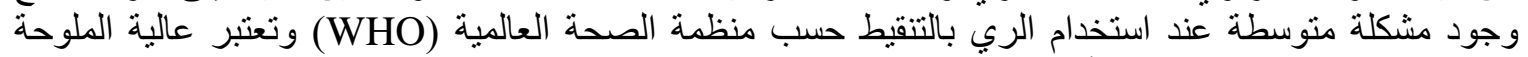

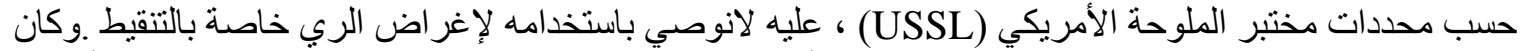
مستوى تراكيز بكتريا القولون والمتطلب الحيوي للأوكسجين والمواد المادية الصلبة الكلية العالقة مناسبة لسقي أنشجار

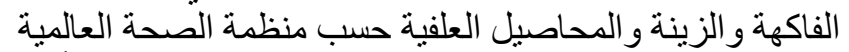

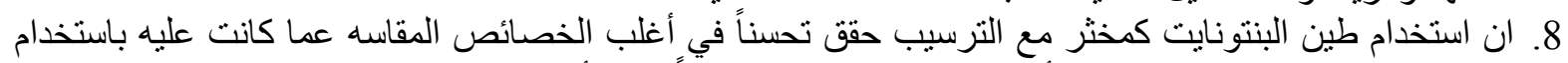

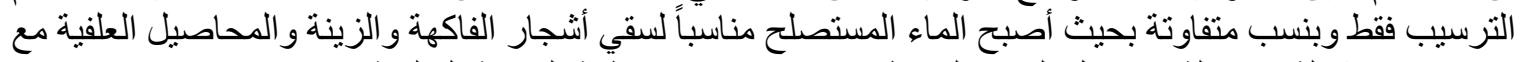
عدم وجود مشكلة في حالة استعمال الري بالتنقيط وحسب محددات منظمة الصحة العالمية .

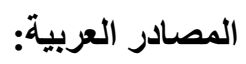

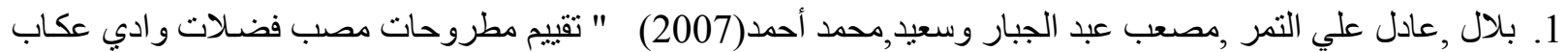

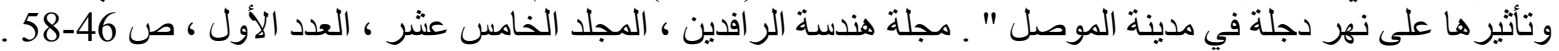

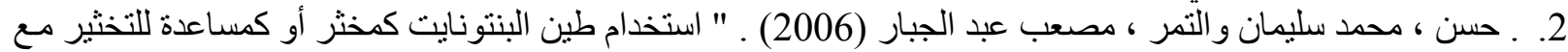

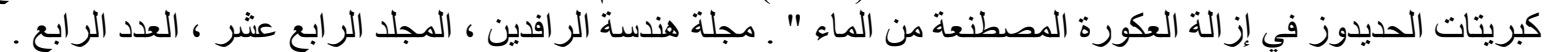

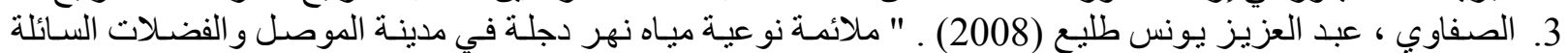

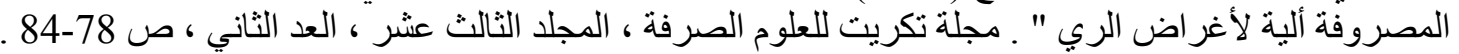

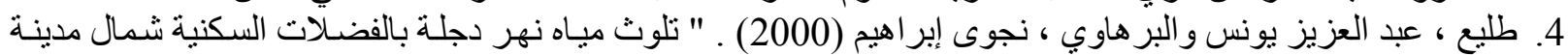

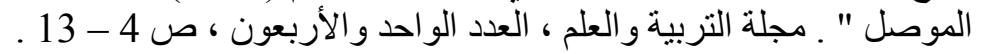

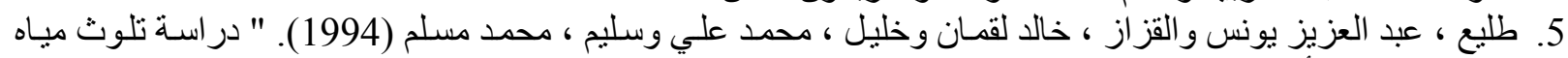

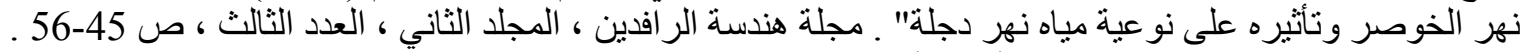

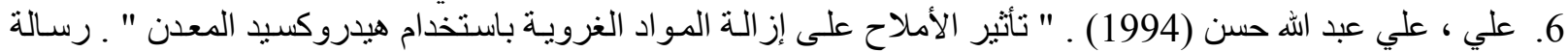

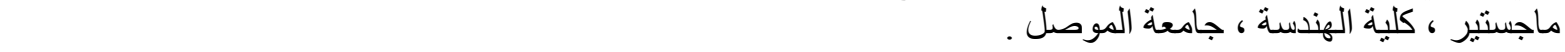
7. عباوي ، سعاد عبد وحسن ، محمود سليمان (1990) ـ " الهندسة العملية للبيئة فحوصـات المـاء " ـ دار الحكمة للطباعة

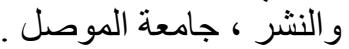

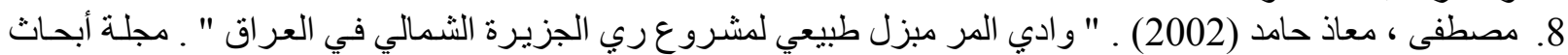

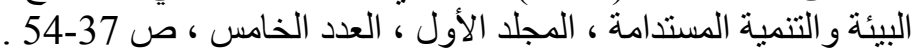

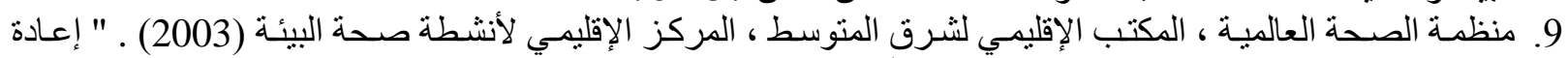

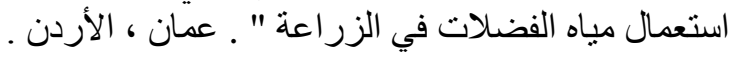

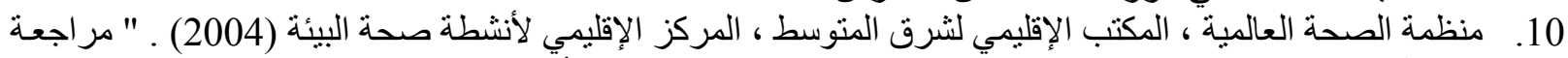

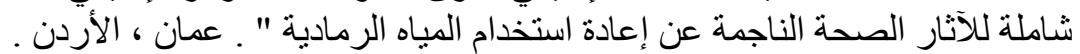

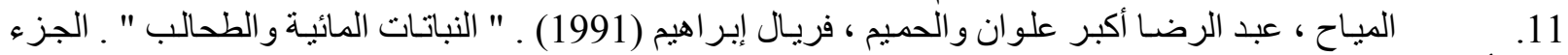

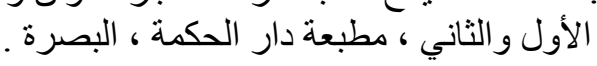

المصادر الإنكليزية :

12. Anderson, D.M. (1997). " Turning back the harmful red tide ", Journal of Nature, Vol. 388, PP.513-514.

13. APHA, AWWA, WPCF (1985). "Standard methods for the examination of water and waste water". $16^{\text {th }}$ ed, Am. Public Healthy Assoc, Washington, D.C, USA .

14. BENSON, H.J (2002). " Microbiological Applications, Laboratory Manual in Genel Microbiology ". Published by McGraw-Hill, New York, Eighth Edition .

15. Dentel, S.K, and Gossett, J.M (1988). "Mechanisms of Coagulation with aluminum Salts" .Jour of AWWA, Vol. 80, No.9, P. 187.

16. Lund, E. and Nissen, B. (1986) . " Low Technology water Purification By Bentonite clay flocculation as performed in Sadanese villages verological Examination ". water Reasearch, Vol. 20, No. 1, P.37 . 
17. McCheet, T.J.and E.Steel (1991). " water Supply and Sewaga " . $6^{\text {th }}$ ed, Mc Graw-Hill, Inc .

18. Sengco, M.R., Li, A., Tugend, K., Kulis, D. and Anderson, D.M. (2001) . " Removal of red-and brown- tide Cells using clay flocculation", I.laboratory experiments with Gymnodinium breve and Aureococus anophage fferens. Mar. Ecol. Prog-Ser . Vol. 210, PP. 41-53.

تم اجراء البحث في كلية ألهندسة = جامعة ألموصل 